\title{
Bioactive Compounds in Wild Nettle (Urtica dioica L.) Leaves and Stalks: Polyphenols and Pigments upon Seasonal and Habitat Variations
}

\author{
Maja Repajić $^{1}$ (D), Ena Cegledi ${ }^{1}$, Zoran Zorić ${ }^{1}$ (D), Sandra Pedisić ${ }^{1}$ (D) Ivona Elez Garofulić ${ }^{1, *}$, Sanja Radman $^{2}$, \\ Igor Palčić $^{3}$ iD and Verica Dragović-Uzelac ${ }^{1} \mathbb{D}$ \\ 1 Faculty of Food Technology and Biotechnology, University of Zagreb Pierottijeva 6, 10000 Zagreb, Croatia; \\ maja.repajic@pbf.unizg.hr (M.R.); ecegledi@pbf.hr (E.C.); zzoric@pbf.hr (Z.Z.); \\ sandra.pedisic@pbf.unizg.hr (S.P.); vdragov@pbf.hr (V.D.-U.) \\ 2 Faculty of Agriculture, University of Zagreb, Svetošimunska cesta 25, 10000 Zagreb, Croatia; sradman@agr.hr \\ 3 Institute of Agriculture and Tourism, Karla Huguesa 8, 52440 Poreč, Croatia; palcic@iptpo.hr \\ * Correspondence: ivona.elez@pbf.unizg.hr
}

Citation: Repajić, M.; Cegledi, E.;

Zorić, Z.; Pedisić, S.; Elez Garofulić, I.;

Radman, S.; Palčić, I.;

Dragović-Uzelac, V. Bioactive

Compounds in Wild Nettle (Urtica

dioica L.) Leaves and Stalks:

Polyphenols and Pigments upon

Seasonal and Habitat Variations.

Foods 2021, 10, 190. https://doi.org/ $10.3390 /$ foods 10010190

Received: 23 November 2020

Accepted: 14 January 2021

Published: 18 January 2021

Publisher's Note: MDPI stays neutral with regard to jurisdictional claims in published maps and institutional affiliations.

Copyright: (c) 2021 by the authors. Licensee MDPI, Basel, Switzerland This article is an open access article distributed under the terms and conditions of the Creative Commons Attribution (CC BY) license (https:// creativecommons.org/licenses/by/ $4.0 /)$
Abstract: This study evaluated the presence of bioactives in wild nettle leaves and stalks during the phenological stage and in the context of natural habitat diversity. Thus, wild nettle samples collected before flowering, during flowering and after flowering from 14 habitats situated in three different regions (continental, mountain and seaside) were analyzed for low molecular weight polyphenols, carotenoids and chlorophylls using UPLC-MS/MS and HPLC analysis, while the ORAC method was performed for the antioxidant capacity measurement. Statistical analysis showed that, when compared to the stalks, nettle leaves contained significantly higher amounts of analyzed compounds which accumulated in the highest yields before flowering (polyphenols) and the flowering stage (pigments). Moreover, nettle habitat variations greatly influenced the amounts of analyzed bioactives, where samples from the continental area contained higher levels of polyphenols, while seaside region samples were more abundant with pigments. The levels of ORAC followed the same pattern, being higher in leaves samples collected before and during flowering from the continental habitats. Hence, in order to provide the product's maximum value for consumers' benefit, a multidisciplinary approach is important for the selection of a plant part as well as its phenological stage with the highest accumulation of bioactive compounds.

Keywords: nettle leaves and stalks; phenological stage; location; accelerated solvent extraction; UPLC-MS/MS; polyphenols; chlorophylls; carotenoids; antioxidant capacity; ORAC

\section{Introduction}

Nettle (Urtica dioica L.) is a perennial wild plant of the Urticaceae family, genus Urtica, which is widespread in Europe, Asia, America and part of Africa, and has been adapted to different climatic conditions [1,2]. Nettle has long been used in the food, cosmetic and pharmaceutical industries due to its nutritional and health potential, as all parts of nettle (leaves, stalks and roots) show a rich composition of bioactive compounds with high antioxidant capacity [2,3] Previous studies have shown that nettle leaves and stalks are a rich source of vitamins A, B and C, minerals (iron, potassium, calcium, magnesium), polyphenols such as phenolic acids and flavonoids as well as pigments, especially chlorophyll and carotenoids [4-11]. In accordance with the above, aerial parts of nettle have anti-inflammatory and therapeutic effects; these nettle parts are used in the treatment of arthritis, anemia, allergies, joint pain and urinary tract infections, have a diuretic effect and are used to strengthen hair [3,12]. Besides aerial parts, nettle root also presents a rich source of various compounds such as protein lectin, sterols, polysaccharides, lignans and phenols $[5,7,13,14]$ and is mostly used in the treatment of benign prostatic hyperplasia [15]. Apart from medicinal use, other applications of nettle include food preparation, where it 
is consumed in the form of tea, soup, stew or salad [3], or for commercial extraction of chlorophyll, which is used as a green coloring agent (E140) [16].

For medicinal purpose and medicinal preparations, nettle is mostly often used in the form of liquid or dry extract; thus, it is important to apply extraction method that will give a highly stabile extract with the greatest possible content of bioactive ingredients. Therefore, new extraction methods are increasingly being used and one of them is accelerated solvent extraction (ASE). In addition to being an efficient method, it uses less solvent, shortens the extraction time and more effectively isolates the target components [17].

Aside from extraction method, extract quality and richness in bioactives also depends on used plant material, either wild or cultivated, where its chemical composition and consequently antioxidant capacity are influenced by environmental, genotypic and phenotypic factors.

Different parts of plant may contain different amounts of particular compounds, e.g., nettle leaves accumulate higher amounts of polyphenols and chlorophylls in comparison with stalks $[6,7,18]$. In general, leaves are the richest part of a nettle in bioactive compounds, therefore they are mostly used in processing. However, changes in chemical composition and compounds' distribution occur with plant's maturity, where bioactive compounds are present in different proportions during different phenological stages. For example, the content of polyphenols decreases with growth and maturity of the plant [19]. Bioactive compounds are produced in response to different forms of (a)biotic stresses, as well as to fulfil important physiological tasks (attracting pollinators, establishing symbiosis, providing structural components to lignified cell walls of vascular tissues, etc.) [20]. These processes are often connected to specific phenological stages. Hence, harvest time depends on the type of final product. Although opinion on nettle optimal harvest time differs among various authors [3], Moore (1993) [21] stated that for juices and other fresh preparations, nettle leaves are best picked in spring or early summer (before flowering), and according to Upton (2013) [3] for dried preparations, it is best to harvest from mid-spring to late summer. If nettle is used for food purposes, the recommended harvest should be at the pre-flowering and flowering phases, certainly before the appearance of the seeds when it contains the least bioactive ingredients [3].

Nevertheless, nettle herb is mostly wild-harvested [3]. Concerning the natural habitat and climate, nettle is a quite adaptable plant. It grows in areas characterized by mild to temperate climates and prefers open or partly shady habitats with plenty of moisture such as forests, by rivers or streams and on roadsides [2]. Still, accumulation of polyphenols and pigments varies upon climate and habitat diversity. Plants grown in cold climates often show greater antioxidant properties, as a result of oxidative stress defense [22], while pigments synthesis is enhanced due to exposure to higher temperatures and more sunlight $[23,24]$.

Although mentioned scientific literature provides data regarding nettle chemical composition, to our best knowledge there are no comprehensive studies on polyphenols and pigments constituents and their accumulation in wild nettle leaves and stalks during different vegetation periods of growing across diverse regions. These cognitions could be beneficial input data in a production of liquid and dry extracts. Therefore, the current study aimed to examine the presence and profile of low molecular weight polyphenols, carotenoids and chlorophylls as well as to determine antioxidant capacity in wild nettle leaves and stalks collected during three phenological stages (before flowering, during flowering and after flowering) from 14 different natural habitats situated in three regions in Croatia.

\section{Materials and Methods}

\subsection{Chemicals}

HPLC grade acetonitrile was procured from J.T. Baker Chemicals (Deventer, Netherlands). Purified water was obtained by a Milli-Q water purification system (Millipore, Bedford, MA, USA). Ethanol (96\%) was purchased from Gram-mol d.o.o. (Zagreb, Croa- 
tia) and formic acid (98-100\%) from T.T.T. d.o.o. (Sveta Nedjelja, Croatia). Commercial standards of quercetin-3-glucoside, kaempferol-3-rutinoside, myricetin, caffeic acid, gallic acid, ferulic acid, sinapic acid, quinic acid, chlorogenic acid, $p$-coumaric acid, esculetin, scopoletin, $\alpha$-carotene, $\beta$-carotene, chlorophyll $a$ and chlorophyll $b$ were purchased from Sigma-Aldrich (St. Louis, MO, USA). Epicatechin, catechin, epigallocatechin gallate, epicatechin gallate, apigenin, luteolin and naringenin were obtained from Extrasynthese (Genay, France), while quercetin-3-rutinoside was procured from Acros Organics (Thermo Fisher Scientific, Geel, Belgium). Apigenin was dissolved in ethanol with $0.5 \%(v / v)$ dimethyl sulfoxide, standards of carotenoids and chlorophylls in $n$-hexane. Other standards were prepared as a stock solution in methanol, and working standard solutions were prepared by diluting the stock solutions to yield five concentrations.

\subsection{Plant Material}

Samples of wild nettle (Urtica dioica L.) were collected at three phenological stages [(I) before flowering, (II) during flowering and (III) after flowering] during 2019 from different habitats in Croatia belonging to three regions (continental, mountain and seaside) (Table 1). Plant material was identified by using usual keys and iconographies with support of Department of Vegetable Crops, Faculty of Agriculture, University of Zagreb (Croatia). Immediately after harvesting, leaves were separated from stalks and samples were stored at $-18{ }^{\circ} \mathrm{C}$, freeze-dried (Alpha 1-4 LSCPlus, Martin Christ Gefriertrocknungsanlagen $\mathrm{GmbH}$, Osterode am Harz, Germany) and afterwards grinded into fine powder using a commercial grinder (GT11, Tefal, Rumilly, France). Obtained powders were immediately analyzed for total solids by drying at $103 \pm 2{ }^{\circ} \mathrm{C}$ to constant mass [25] and further used for the extraction. Content of dry matter in samples was $>95 \%$.

Table 1. Location and weather characteristics of wild nettle (Urtica dioica L.) habitats.

\begin{tabular}{|c|c|c|c|c|c|c|c|c|c|}
\hline \multirow{3}{*}{ Region } & \multirow{3}{*}{ Location } & \multirow{3}{*}{$\begin{array}{c}\text { Altitude/ } \\
\text { Latitude/Longitude }\end{array}$} & \multirow{3}{*}{$\begin{array}{c}\text { Weather } \\
\text { Parameters }\end{array}$} & \multicolumn{6}{|c|}{ Phenological Stage } \\
\hline & & & & \multicolumn{2}{|c|}{$\begin{array}{c}\text { I } \\
\text { Before Flowering }\end{array}$} & \multicolumn{2}{|c|}{$\begin{array}{c}\text { II } \\
\text { During Flowering }\end{array}$} & \multicolumn{2}{|c|}{$\begin{array}{c}\text { III } \\
\text { After Flowering }\end{array}$} \\
\hline & & & & April & May & June & July & September & October \\
\hline \multirow{24}{*}{ 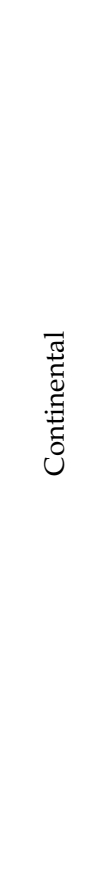 } & \multirow{4}{*}{ Sela Žakanjska } & \multirow{4}{*}{$\begin{array}{c}244 \mathrm{~m} \\
45^{\circ} 36^{\prime} 27.80^{\prime \prime} \mathrm{N} \\
15^{\circ} 20^{\prime} 38.21^{\prime \prime} \mathrm{E}\end{array}$} & a.d. T $\left({ }^{\circ} \mathrm{C}\right)$ & 11.0 & 13.4 & 22.6 & 22.0 & 16.3 & 12.7 \\
\hline & & & $\mathrm{T} \min \left({ }^{\circ} \mathrm{C}\right)$ & -0.1 & 0.4 & 11.4 & 9.2 & 2.9 & 0.7 \\
\hline & & & $\mathrm{T} \max \left({ }^{\circ} \mathrm{C}\right)$ & 27.7 & 26.5 & 34.7 & 35.6 & 30.5 & 26.7 \\
\hline & & & a.p. $(\mathrm{mm})$ & 143.4 & 170.1 & 73.8 & 85.4 & 101.8 & 55.6 \\
\hline & \multirow{4}{*}{ Sopčić Vrh } & \multirow{4}{*}{$\begin{array}{c}177 \mathrm{~m} \\
45^{\circ} 34^{\prime} 14.88^{\prime \prime} \mathrm{N} \\
15^{\circ} 20^{\prime} 24.98^{\prime \prime} \mathrm{E}\end{array}$} & a.d. T $\left({ }^{\circ} \mathrm{C}\right)$ & 11.0 & 13.4 & 22.6 & 22.0 & 16.3 & 12.7 \\
\hline & & & $\mathrm{T} \min \left({ }^{\circ} \mathrm{C}\right)$ & -0.1 & 0.4 & 11.4 & 9.2 & 2.9 & 0.7 \\
\hline & & & $\mathrm{T} \max \left({ }^{\circ} \mathrm{C}\right)$ & 27.7 & 26.5 & 34.7 & 35.6 & 30.5 & 26.7 \\
\hline & & & a.p. (mm) & 143.4 & 170.1 & 73.8 & 85.4 & 101.8 & 55.6 \\
\hline & \multirow{4}{*}{ Žakanje } & \multirow{4}{*}{$\begin{array}{c}178 \mathrm{~m} \\
45^{\circ} 36^{\prime} 34.38^{\prime \prime} \mathrm{N} \\
15^{\circ} 20^{\prime} 14.96^{\prime \prime} \mathrm{E}\end{array}$} & a.d. T $\left({ }^{\circ} \mathrm{C}\right)$ & 11.0 & 13.4 & 22.6 & 22.0 & 16.3 & 12.7 \\
\hline & & & $\mathrm{T} \min \left({ }^{\circ} \mathrm{C}\right)$ & -0.1 & 0.4 & 11.4 & 9.2 & 2.9 & 0.7 \\
\hline & & & $\mathrm{T} \max \left({ }^{\circ} \mathrm{C}\right)$ & 27.7 & 26.5 & 34.7 & 35.6 & 30.5 & 26.7 \\
\hline & & & a.p. $(\mathrm{mm})$ & 143.4 & 170.1 & 73.8 & 85.4 & 101.8 & 55.6 \\
\hline & \multirow{4}{*}{ Zagreb I (Gračani) } & \multirow{4}{*}{$\begin{array}{c}119 \mathrm{~m} \\
45^{\circ} 51^{\prime} 31.10^{\prime \prime} \mathrm{N} \\
15^{\circ} 58^{\prime} 19.34^{\prime \prime} \mathrm{E}\end{array}$} & a.d. T $\left({ }^{\circ} \mathrm{C}\right)$ & 12.4 & 13.7 & 23.8 & 22.9 & 17.2 & 13.2 \\
\hline & & & $\mathrm{T} \min \left({ }^{\circ} \mathrm{C}\right)$ & 1.9 & 2.1 & 13.3 & 10.4 & 4.6 & 2.2 \\
\hline & & & $\mathrm{T} \max \left({ }^{\circ} \mathrm{C}\right)$ & 27.1 & 26.1 & 34.6 & 35.9 & 33.1 & 25.9 \\
\hline & & & a.p. $(\mathrm{mm})$ & 81.1 & 147.7 & 70.8 & 76.8 & 150.1 & 42.3 \\
\hline & \multirow{4}{*}{ Zagreb II (Vrapče) } & \multirow{4}{*}{$\begin{array}{c}119 \mathrm{~m} \\
45^{\circ} 49^{\prime} 8.69^{\prime \prime} \mathrm{N} \\
15^{\circ} 52^{\prime} 49.84^{\prime \prime} \mathrm{E}\end{array}$} & a.d. $\mathrm{T}\left({ }^{\circ} \mathrm{C}\right)$ & 13.6 & 14.3 & 24.8 & 24.1 & 18.4 & 14.8 \\
\hline & & & $\mathrm{T} \min \left({ }^{\circ} \mathrm{C}\right)$ & 5.4 & 5.6 & 15.1 & 14.0 & 8.5 & 5.2 \\
\hline & & & $\mathrm{T} \max \left({ }^{\circ} \mathrm{C}\right)$ & 22.9 & 27.1 & 27.3 & 35.5 & 32.7 & 24.6 \\
\hline & & & a.p. $(\mathrm{mm})$ & 85.2 & 123.1 & 83.9 & 65.8 & 131.6 & 39.5 \\
\hline & \multirow{4}{*}{ Koretići } & \multirow{4}{*}{$\begin{array}{c}410 \mathrm{~m} \\
45^{\circ} 48^{\prime} 47.23^{\prime \prime} \mathrm{N} \\
15^{\circ} 33^{\prime} 36.18^{\prime \prime} \mathrm{E}\end{array}$} & a.d. T $\left({ }^{\circ} \mathrm{C}\right)$ & 9.0 & 9.9 & 20.4 & 19.6 & 14.5 & 13.3 \\
\hline & & & $\mathrm{T} \min \left({ }^{\circ} \mathrm{C}\right)$ & -3.0 & -1.8 & 9.8 & 7.2 & 1.5 & 3.5 \\
\hline & & & $\mathrm{T} \max \left({ }^{\circ} \mathrm{C}\right)$ & 22.4 & 21.5 & 31.2 & 30.0 & 28.2 & 22.8 \\
\hline & & & a.p. $(\mathrm{mm})$ & 135.7 & 283.7 & 81.4 & 184.8 & 120.2 & 59.5 \\
\hline
\end{tabular}


Table 1. Cont.

\begin{tabular}{|c|c|c|c|c|c|c|c|c|c|}
\hline \multirow{3}{*}{ Region } & \multirow{3}{*}{ Location } & \multirow{3}{*}{$\begin{array}{c}\text { Altitude/ } \\
\text { Latitude/Longitude }\end{array}$} & \multirow{3}{*}{$\begin{array}{c}\text { Weather } \\
\text { Parameters }\end{array}$} & \multicolumn{6}{|c|}{ Phenological Stage } \\
\hline & & & & \multicolumn{2}{|c|}{$\begin{array}{c}\text { I } \\
\text { Before Flowering }\end{array}$} & \multicolumn{2}{|c|}{$\begin{array}{c}\text { II } \\
\text { During Flowering }\end{array}$} & \multicolumn{2}{|c|}{$\begin{array}{c}\text { III } \\
\text { After Flowering }\end{array}$} \\
\hline & & & & April & May & June & July & September & October \\
\hline \multirow{12}{*}{ 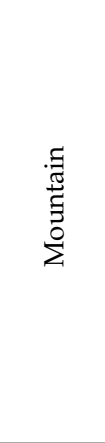 } & \multirow{4}{*}{ Ogulin } & \multirow{4}{*}{$\begin{array}{c}320 \mathrm{~m} \\
45^{\circ} 15^{\prime} 47.84^{\prime \prime} \mathrm{N} \\
15^{\circ} 13^{\prime} 42.36^{\prime \prime} \mathrm{E}\end{array}$} & a.d. T $\left({ }^{\circ} \mathrm{C}\right)$ & 10.8 & 12.4 & 21.6 & 21.4 & 15.6 & 13.0 \\
\hline & & & $\mathrm{T} \min \left({ }^{\circ} \mathrm{C}\right)$ & 0.5 & 0.5 & 11.8 & 8.3 & 2.8 & 3.0 \\
\hline & & & $\mathrm{T} \max \left({ }^{\circ} \mathrm{C}\right)$ & 25.5 & 25.1 & 33.4 & 33.0 & 29.3 & 25.9 \\
\hline & & & a.p. $(\mathrm{mm})$ & 167.4 & 319.2 & 139.5 & 109.4 & 143.6 & 64.2 \\
\hline & \multirow{4}{*}{ Čovići I } & \multirow{4}{*}{$\begin{array}{c}456 \mathrm{~m} \\
44^{\circ} 49^{\prime} 44.07^{\prime \prime} \mathrm{N} \\
15^{\circ} 17^{\prime} 57.29^{\prime \prime} \mathrm{E}\end{array}$} & a.d. T $\left({ }^{\circ} \mathrm{C}\right)$ & 9.4 & 11.1 & 20.1 & 19.7 & 14.0 & 10.6 \\
\hline & & & $\mathrm{T} \min \left({ }^{\circ} \mathrm{C}\right)$ & -2.1 & -1.3 & 7.6 & 5.5 & -2.0 & 1.2 \\
\hline & & & $\mathrm{T} \max \left({ }^{\circ} \mathrm{C}\right)$ & 24.8 & 25.0 & 34.1 & 34.5 & 29.6 & 25.1 \\
\hline & & & a.p. (mm) & 138.6 & 189.3 & 25.1 & 106.2 & 106.9 & 31.8 \\
\hline & \multirow{4}{*}{ Čovići II } & \multirow{4}{*}{$\begin{array}{c}456 \mathrm{~m} \\
44^{\circ} 49^{\prime} 50.05^{\prime \prime} \mathrm{N} \\
15^{\circ} 17^{\prime} 57.18^{\prime \prime} \mathrm{E}\end{array}$} & a.d. T $\left({ }^{\circ} \mathrm{C}\right)$ & 9.4 & 11.1 & 20.1 & 19.7 & 14.0 & 10.6 \\
\hline & & & $\mathrm{T} \min \left({ }^{\circ} \mathrm{C}\right)$ & -2.1 & -1.3 & 7.6 & 5.5 & -2.0 & 1.2 \\
\hline & & & $\mathrm{T} \max \left({ }^{\circ} \mathrm{C}\right)$ & 24.8 & 25.0 & 34.1 & 34.5 & 29.6 & 25.1 \\
\hline & & & a.p. $(\mathrm{mm})$ & 138.6 & 189.3 & 25.1 & 106.2 & 106.9 & 31.8 \\
\hline \multirow{20}{*}{ 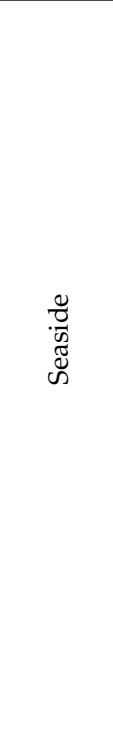 } & \multirow{4}{*}{ Poreč } & \multirow{4}{*}{$\begin{array}{c}0.34 \mathrm{~m} \\
45^{\circ} 13^{\prime} 37.03^{\prime \prime} \mathrm{N} \\
13^{\circ} 35^{\prime} 39.64^{\prime \prime} \mathrm{E}\end{array}$} & a.d. $\mathrm{T}\left({ }^{\circ} \mathrm{C}\right)$ & 13.0 & 14.5 & 24.3 & 24.9 & 19.4 & 15.7 \\
\hline & & & $\mathrm{T} \min \left({ }^{\circ} \mathrm{C}\right)$ & 3.9 & 6.0 & 13.2 & 13.4 & 7.3 & 6.3 \\
\hline & & & $\mathrm{T} \max \left({ }^{\circ} \mathrm{C}\right)$ & 23.5 & 22.7 & 33.6 & 33.6 & 30.9 & 25.7 \\
\hline & & & a.p. $(\mathrm{mm})$ & 116.1 & 210.0 & 7.3 & 58.7 & 143.2 & 38.6 \\
\hline & \multirow{4}{*}{ Limski zaljev } & \multirow{4}{*}{$\begin{array}{c}17 \mathrm{~m} \\
45^{\circ} 7^{\prime} 56.45^{\prime \prime} \mathrm{N} \\
13^{\circ} 39^{\prime} 13.78^{\prime \prime} \mathrm{E}\end{array}$} & a.d. T $\left({ }^{\circ} \mathrm{C}\right)$ & 13.0 & 14.5 & 24.3 & 24.9 & 19.4 & 15.7 \\
\hline & & & $\mathrm{T} \min \left({ }^{\circ} \mathrm{C}\right)$ & 3.9 & 6.0 & 13.2 & 13.4 & 7.3 & 6.3 \\
\hline & & & $\mathrm{T} \max \left({ }^{\circ} \mathrm{C}\right)$ & 23.5 & 22.7 & 33.6 & 33.6 & 30.9 & 25.7 \\
\hline & & & a.p. $(\mathrm{mm})$ & 116.1 & 210.0 & 7.3 & 58.7 & 143.2 & 38.6 \\
\hline & \multirow{4}{*}{ Bale } & \multirow{4}{*}{$\begin{array}{c}129 \mathrm{~m} \\
45^{\circ} 2^{\prime} 25.93^{\prime \prime} \mathrm{N} \\
13^{\circ} 47^{\prime} 8.88^{\prime \prime} \mathrm{E}\end{array}$} & a.d. T $\left({ }^{\circ} \mathrm{C}\right)$ & 13.4 & 14.4 & 23.9 & 24.5 & 19.8 & 15.5 \\
\hline & & & $\mathrm{T} \min \left({ }^{\circ} \mathrm{C}\right)$ & 4.9 & 4.5 & 13.8 & 13.6 & 7.5 & 5.8 \\
\hline & & & $\mathrm{T} \max \left({ }^{\circ} \mathrm{C}\right)$ & 23.7 & 24.5 & 34.0 & 34.3 & 33.0 & 25.5 \\
\hline & & & a.p. (mm) & 129.5 & 264.7 & 37.4 & 71.5 & 91.1 & 42.0 \\
\hline & \multirow{4}{*}{ Vodnjan } & \multirow{4}{*}{$\begin{array}{c}141 \mathrm{~m} \\
44^{\circ} 57^{\prime} 28.79^{\prime \prime} \mathrm{N} \\
13^{\circ} 51^{\prime} 6.10^{\prime \prime} \mathrm{E}\end{array}$} & a.d. T $\left({ }^{\circ} \mathrm{C}\right)$ & 13.4 & 14.4 & 23.9 & 24.5 & 19.8 & 15.5 \\
\hline & & & $\mathrm{T} \min \left({ }^{\circ} \mathrm{C}\right)$ & 4.9 & 4.5 & 13.8 & 13.6 & 7.5 & 5.8 \\
\hline & & & $\mathrm{T} \max \left({ }^{\circ} \mathrm{C}\right)$ & 23.7 & 24.5 & 34.0 & 34.3 & 33.0 & 25.5 \\
\hline & & & a.p. $(\mathrm{mm})$ & 129.5 & 264.7 & 37.4 & 71.5 & 91.1 & 42.0 \\
\hline & \multirow{4}{*}{ Muntrilj } & \multirow{4}{*}{$\begin{array}{c}342 \mathrm{~m} \\
45^{\circ} 14^{\prime} 30.84^{\prime \prime} \mathrm{N} \\
13^{\circ} 48^{\prime} 38.44^{\prime \prime} \mathrm{E}\end{array}$} & a.d. T $\left({ }^{\circ} \mathrm{C}\right)$ & 11.1 & 12.5 & 22.2 & 22.3 & 16.4 & 13.1 \\
\hline & & & $\mathrm{T} \min \left({ }^{\circ} \mathrm{C}\right)$ & 0.5 & 1.1 & 11.2 & 9.5 & 2.3 & 2.5 \\
\hline & & & $\mathrm{T} \max \left({ }^{\circ} \mathrm{C}\right)$ & 23.3 & 23.5 & 35.8 & 36.1 & 31.7 & 25.2 \\
\hline & & & a.p. $(\mathrm{mm})$ & 135.1 & 295.1 & 26.0 & 72.6 & 90.5 & 26.4 \\
\hline
\end{tabular}

a.d. $\mathrm{T}=$ average day temperature, $\mathrm{T}$ min $=$ minimal day temperature, $\mathrm{T}$ max $=$ maximal day temperature, a.p. $=$ accumulated precipitation.

\subsection{Extraction Conditions}

Extraction of polyphenols and pigments from dry nettle leaves and stalks was carried out by ASE. Extraction conditions and procedure were adopted from the study of Repajić et al. (2020) [11]: extraction was performed in Dionex ${ }^{\mathrm{TM}}$ ASE ${ }^{\mathrm{TM}} 350$ Accelerated Solvent Extractor (Thermo Fisher Scientific Inc., Sunnyvale, CA, USA) using ethanol (96\%) as the extraction solvent. Extraction was accomplished in $34 \mathrm{~mL}$ stainless steel cells fitted with 2 cellulose filters (Dionex ${ }^{\mathrm{TM}}$ 350/150 Extraction Cell Filters, Thermo Fisher Scientific Inc., Sunnyvale, CA, USA), within which $1 \mathrm{~g}$ of sample was mixed with $2 \mathrm{~g}$ of diatomaceous earth, placed in cell and filled up with diatomaceous earth to the full cell volume. Extraction parameters differed for leaves and stalks: leaves were extracted under $110^{\circ} \mathrm{C}$ with $10 \mathrm{~min}$ of static extraction time and 4 cycles, while stalk extracts were obtained at $80^{\circ} \mathrm{C}, 5 \mathrm{~min}$ of static extraction time and 4 cycles (parameters previously optimized). Other extraction parameters remained fixed for the extraction of both plant parts, namely pressure $10.34 \mathrm{MPa}, 30 \mathrm{~s}$ of purge with nitrogen and $50 \%$ of flushing. Obtained extracts were collected in $250 \mathrm{~mL}$ glass vessel with Teflon septa, transferred into $50 \mathrm{~mL}$ volume flask and made up to volume with the extraction solvent. All extracts were filtered through a $0.45 \mu \mathrm{m}$ membrane filter (Macherey-Nagel GmbH, Düren, Germany) prior to further analysis. All extracts have been prepared in a duplicate $(n=2)$. 


\subsection{UPLC-MS/MS Conditions}

Identification and quantification of phenolics were performed on UPLC-MS/MS in both ionization modes on a 6430 QQQ mass spectrometer Agilent Technologies (Agilent, Santa Clara, CA, USA). Analytes were ionized using ESI ion source with nitrogen as desolvation and collision gas (temperature $300^{\circ} \mathrm{C}$, flow $11 \mathrm{~L} \mathrm{~h}^{-1}$ ), capillary voltage, $+4-3.5 \mathrm{kV}^{-1}$ and the pressure of nebulizer was set at 40 psi. The mass spectrometer was linked to UPLC system (Agilent series 1290 RRLC instrument) consisted of binary pump, autosampler and a column compartment thermostat. Reversed phase separation was performed on a Zorbax Eclipse Plus C18 column $100 \times 2.1 \mathrm{~mm}$ with $1.8 \mu \mathrm{m}$ particle size (Agilent). Column temperature was set at $35^{\circ} \mathrm{C}$ and the injection volume was $2.5 \mu \mathrm{L}$. The solvent compositions and the gradient conditions used were as described previously by Elez Garofulić et al. (2018) [26]. For instrument control and data processing, Agilent MassHunter Workstation Software (ver. B.04.01) was used. Quantitative determination was carried out using the calibration curves of the standards, where protocatechuic acid, gentisic acid, syringic acid and $p$-hydroxybenzoic acid were calculated as gallic acid equivalents and cinnamic acid according to $p$-coumaric acid. Isorhamnetin rutinoside, quercetin rhamnoside, quercetin, isorhamnetin, quercetin pentoside, quercetin acetylhexoside, quercetin acetylrutinoside and quercetin pentosylhexoside were calculated according to quercetin-3-glucoside, kaempferol hexoside, kaempferol pentoside, kaempferol rhamnoside, kaempferol pentosylhexoside and kaempferol according to kaempferol-3-rutinoside, apigenin hexoside and genistein according to apigenin, while umbelliferone was expressed as scopoletin equivalents. All analyses have been performed in a duplicate and concentrations of analyzed compounds are expressed as $\mathrm{mg} 100 \mathrm{~g}^{-1}$ of dry matter $(\mathrm{dm})(\mathrm{N}=4)$.

\subsection{HPLC-UV-VIS/PDA Conditions}

The carotenoids and chlorophylls identification and quantification were performed using Agilent Infinity 1260 system equipped with Agilent 1260 photodiode array detector (PDA; Agilent, Santa Clara, CA, USA) with an automatic injector and Chemstation software (ver. C.01.03).

The separation of carotenoids and chlorophylls was performed using Develosil RPAqueus C 30 column $(250 \times 4.6 \mathrm{~mm}$ i.d. $3 \mu \mathrm{m}$, Phenomenex, Torrance, CA, USA). The solvent composition and the used gradient conditions were described previously by CastroPuyana et al. (2017) [27]. The mixture of MeOH:MTBE:water (90:7:3, v/v/v) (A) and MeOH:MTBE $(10: 90, v / v)$ (B) formed the mobile phase. The injection volume was $10 \mu \mathrm{L}$ and the flow rate was kept at $0.8 \mathrm{~mL} \mathrm{~min}{ }^{-1}$. The chromatogram was monitored by scanning from 240 to $770 \mathrm{~nm}$ and the signal intensities detected at $450 \mathrm{~nm}$ and $660 \mathrm{~nm}$ were used for carotenoid and chlorophyll quantitation. Identification was carried out by comparing retention times and spectral data with those of the authentic standards ( $\alpha$ - and $\beta$-carotene, chlorophyll $a$ and $b$ ) or in case of unavailability of standards by comparing the absorption spectra reported in the literature [28,29]. Quantifications were made by the external standard calculation, using calibration curves of the standards $\alpha$-carotene, $\beta$-carotene, chlorophyll $a$ and chlorophyll $b$. The quantification of individual carotenoid compounds (neoxantine, violaxantine, lutein and its derivatives, derivative of zeaxantine and lycopene) was calculated as $\beta$-carotene equivalents and derivatives of chlorophylls as chlorophyll $a$ and $b$ equivalents using the equation based on the calibration curves, respectively. All determinations have been performed in a duplicate and results are expressed as $\mathrm{mg} 100 \mathrm{~g}^{-1}$ $\mathrm{dm}(\mathrm{N}=4)$.

\subsection{ORAC Determination}

The procedure was based on a previously reported method [30,31] with slight modifications. Briefly, a 96 wells black microplate was prepared containing $150 \mu \mathrm{L}$ of fluorescein solution $(70.30 \mathrm{nM})$ and $25 \mu \mathrm{L}$ of blank (75 $\mu \mathrm{M}$ phosphate buffer, $\mathrm{pH}$ 7.4), Trolox standard (3.24-130.88 $\mu \mathrm{M}$ ) or sample (appropriate diluted) were added. The plate was incubated for $30 \mathrm{~min}$ at $37^{\circ} \mathrm{C}$. After the first three cycles (representing the baseline signal), AAPH 
(240 mM) was injected into each well to initiate the peroxyl radical generation. Fluorescence intensity (excitation at $485 \mathrm{~nm}$ and emission at $528 \mathrm{~nm}$ ) was monitored every 90 sec over a total measurement period of 120 min using an automated plate reader (BMG LABTECH, Offenburg, Germany) and data were analyzed by MARS 2.0 software. The results were expressed as mmol Trolox equivalent (TE) $100 \mathrm{~g}^{-1}$ of $\mathrm{dm}$. Determinations were carried out in duplicate $(\mathrm{N}=4)$.

\subsection{Statistical Analysis}

Statistica ver. 10.0 software (Statsoft Inc., Tulsa, OK, USA) was applied for the statistical analysis. Full factorial randomized design was designated for the experimental part and descriptive statistic was used for the basic data evaluation. Continuous variables (polyphenols, pigments and antioxidant capacity) were analyzed by multifactorial analysis of variance (MANOVA) and marginal mean values were compared with Tukey's HSD test. Relationships between determined compounds and antioxidant capacity were examined by calculated Pearson's correlation coefficients, while possible grouping of the samples according to the examined sources of variations was tested using Principal Component Analysis (PCA). Significance level $p \leq 0.05$ was assigned for all tests.

\section{Results and Discussion}

This study examined the influence of plant part (leaves and stalks), phenological stage (before flowering, during flowering and after flowering) and habitat (Table 1) on the concentrations of polyphenols and pigments in wild nettle grown in Croatia. A total of 84 nettle samples were analyzed, where target compounds (polyphenols and pigments) were extracted using ASE and their identification/quantification was assessed by UPLCMS/MS (polyphenols) and HPLC-UV-VIS/PDA (pigments). Moreover, obtained extracts were characterized for their antioxidant capacity by the ORAC method.

\subsection{Influence of Phenological Stage and Habitat on Polyphenols in Nettle Leaves and Stalks}

Table 2 shows detailed polyphenolic profile and mass spectrometric data obtained by UPLC-MS/MS analysis of nettle leaves and stalks. A total of 41 polyphenolic compounds were identified, belonging to the classes of benzoic, cinnamic and other phenolic acids, flavonols, flavan-3-ols, flavones, isoflavones, flavanones and coumarins (Supplementary files 1 \& 2). Among the benzoic acids, compound 35 was identified as gallic acid by comparison of its retention time and mass spectra data with those of an authentic standard. Other benzoic acids were tentatively identified according to their mass fragmentation patterns. Compounds $\mathbf{2}$ and $\mathbf{1 4}$ showed same fragmentation pattern with molecular ion at $m / z 153$ and fragment ion at $m / z 109$, corresponding to the loss of carbon dioxide moiety and implicating the structure of dihydroxybenzoic acids and were therefore according to their polarity tentatively identified as protocatehuic (3,4-dihydroxybenzoic acid) and gentisic acid (1,3-dihydroxybenzoic acid), respectively [32]. Compound 31 showed precursor ion at $m / z 197$ and fragmentation loss of -15 amu corresponding to the loss of methyl radical characteristic for methoxylated phenolic acids and was tentatively identified as syringic acid. Compound 34 showed precursor ion at $m / z 137$ and characteristic fragmentation pattern for deprotonated phenolic acid with loos of -44 amu due to decarboxylation [33] and was assigned as $p$-hydroxybenzoic acid. The composition of benzoic acids in nettle leaves and stalks is in accordance with previous reports $[9,14]$. Among the cinnamic acids, compounds 12, 15, 19, 25 and 32 were identified using authentic standards as caffeic, chlorogenic, $p$-coumaric, ferulic and sinapic acid, respectively. Compound 21 was presented with precursor ion at $m / z 147$, and fragment ion at $m / z 103$ as a result of decarboxylation and was due to its mass spectra data assigned as cinnamic acid [32]. Compound 16 was identified as quinic acid comparing its spectral data and retention time with those of an authentic standard. The composition of cinnamic acids is in accordance with previous reports by Orčić et al. (2014) [14] and Francišković et al. (2017) [34] with the exception of cinnamic acid which was not detected in their research, but was reported previously 
in composition of nettle leaves by Zeković et al. (2017) [35]. The most numerous class of flavonoid polyphenols identified in nettle were flavonols and their glycosides. Compounds 4, 8, 17 and 18 were identified by the authentic standard comparison as kaempferol-3rutinoside, myricetin, quercetin-3-glucoside and quercetin-3-rutinoside, respectively. Other compounds were tentatively identified according to their mass spectra and characteristic fragmentation patterns reported previously. Among the aglycones, compounds 10, 24 and 41 were assigned as quercetin, isorhamnetin and kaempferol due to characteristic molecular ion at $\mathrm{m} / \mathrm{z} 301, \mathrm{~m} / \mathrm{z} 315$ and $\mathrm{m} / \mathrm{z} 285$ [36]. The presence of this aglycones in nettle aerial parts was confirmed previously by Bucar et al. (2006) [37]. Flavonol glycosides lacking authentic standards were tentatively identified according to the characteristic loss of sugar moiety and formation of aglycon fragment ion. Therefore, because of fragment ion at $\mathrm{m} / \mathrm{z} 317$, compound 3 was assigned as isorhamnetin glycoside. Precursor ion at $m / z 625$ implicated glycosylation with rhamnose $(+146 \mathrm{amu})$ and glucose $(+162 \mathrm{amu})$, so it was assigned as isorhametin rutinoside.

Table 2. Mass spectrometric data and identification of polyphenols.

\begin{tabular}{|c|c|c|c|c|c|c|c|}
\hline Compound & $\underset{(\min )}{\mathbf{R t}}$ & $\begin{array}{c}\text { Cone } \\
\text { Voltage } \\
\text { (V) }\end{array}$ & $\begin{array}{l}\text { Collision } \\
\text { Energy } \\
\text { (V) }\end{array}$ & $\begin{array}{l}\text { Ionization } \\
\text { Mode }\end{array}$ & $\begin{array}{l}\text { Precursor Ion } \\
\qquad(\mathrm{m} / \mathrm{z})\end{array}$ & $\begin{array}{l}\text { Fragment Ions } \\
\qquad(\mathrm{m} / \mathrm{z})\end{array}$ & Tentative Identification \\
\hline \multicolumn{8}{|c|}{ Benzoic acids } \\
\hline 2 & 0.828 & 105 & 9 & - & 153 & 109 & $\begin{array}{c}\text { Protocatechuic acid } \\
\text { (3,4-dihydoxybenzoic acid) }\end{array}$ \\
\hline 14 & 0.992 & 100 & 9 & - & 153 & 109 & $\begin{array}{c}\text { Gentisic acid } \\
(2,5-\text { dihydroxybenzoic acid })\end{array}$ \\
\hline 31 & 8.837 & 90 & 7 & - & 197 & 182 & Syringic acid \\
\hline 34 & 11.358 & 80 & 10 & - & 137 & 93 & p-hydroxybenzoic acid \\
\hline 35 & 11.375 & 100 & 10 & - & 169 & 125 & Gallic acid * \\
\hline \multicolumn{8}{|c|}{ Cinnamic acids } \\
\hline 12 & 0.975 & 80 & 10 & - & 179 & 135 & Caffeic acid * \\
\hline 15 & 1.254 & 80 & 10 & - & 353 & 191 & Chlorogenic acid * \\
\hline 19 & 3.332 & 80 & 10 & - & 163 & 119 & $p$-coumaric acid $*$ \\
\hline 21 & 4.490 & 100 & 5 & - & 147 & 103 & Cinnamic acid \\
\hline 25 & 6.158 & 80 & 5 & - & 193 & 178 & Ferulic acid * \\
\hline 32 & 11.012 & 100 & 17 & - & 223 & 193 & Sinapic acid * \\
\hline \multicolumn{8}{|c|}{ Other phenolic acids } \\
\hline 16 & 1.620 & 150 & 20 & - & 191 & 85 & Quinic acid * \\
\hline \multicolumn{8}{|c|}{ Flavonols } \\
\hline 3 & 0.842 & 120 & 15 & + & 625 & 317 & Isorhamnetin rutinoside \\
\hline 4 & 0.856 & 120 & 15 & + & 595 & 287 & Kaempferol-3-rutinoside * \\
\hline 5 & 0.880 & 100 & 5 & + & 449 & 303 & Quercetin rhamnoside \\
\hline 6 & 0.880 & 30 & 5 & + & 449 & 287 & Kaempferol hexoside \\
\hline 8 & 0.907 & 140 & 25 & + & 319 & 273 & Myricetin * \\
\hline 10 & 0.938 & 130 & 15 & - & 301 & 151 & Quercetin \\
\hline 17 & 1.855 & 100 & 5 & + & 465 & 303 & Quercetin-3-glucoside * \\
\hline 18 & 2.461 & 120 & 5 & + & 611 & 303 & Quercetin-3-rutinoside * \\
\hline 24 & 5.963 & 160 & 21 & - & 315 & 300 & Isorhamnetin \\
\hline 27 & 7.106 & 100 & 5 & + & 419 & 287 & Kaempferol pentoside \\
\hline 28 & 7.256 & 100 & 5 & + & 435 & 303 & Quercetin pentoside \\
\hline 29 & 7.930 & 100 & 5 & + & 433 & 287 & Kaempferol rhamnoside \\
\hline 30 & 8.242 & 100 & 10 & + & 507 & 303 & Quercetin acetylhexoside \\
\hline 33 & 11.232 & 100 & 15 & + & 653 & 303 & Quercetin acetylrutinoside \\
\hline 36 & 11.391 & 100 & 15 & + & 597 & 303 & Quercetin pentosylhexoside \\
\hline 39 & 11.758 & 120 & 15 & + & 581 & 287 & $\begin{array}{c}\text { Kaempferol } \\
\text { pentosylhexoside }\end{array}$ \\
\hline 41 & 11.822 & 130 & 0 & - & 285 & 285 & Kaempferol \\
\hline \multicolumn{8}{|c|}{ Flavan-3-ols } \\
\hline 23 & 4.728 & 100 & 5,15 & + & 459 & 289,139 & Epigallocatechin gallate * \\
\hline 37 & 11.615 & 100 & 10 & + & 291 & 139 & Epicatechin * \\
\hline 38 & 11.621 & 100 & 5 & + & 291 & 165 & Catechin * \\
\hline 40 & 11.792 & 100 & 5 & + & 443 & 291 & Epicatechin gallate* \\
\hline
\end{tabular}


Table 2. Cont.

\begin{tabular}{|c|c|c|c|c|c|c|c|}
\hline Compound & $\begin{array}{c}\mathbf{R t} \\
(\mathrm{min})\end{array}$ & $\begin{array}{c}\text { Cone } \\
\text { Voltage } \\
\text { (V) }\end{array}$ & $\begin{array}{c}\text { Collision } \\
\text { Energy } \\
\text { (V) }\end{array}$ & $\begin{array}{l}\text { Ionization } \\
\text { Mode }\end{array}$ & $\begin{array}{c}\text { Precursor Ion } \\
(m / z)\end{array}$ & $\begin{array}{c}\text { Fragment Ions } \\
(\mathrm{m} / \mathrm{z})\end{array}$ & Tentative Identification \\
\hline \multicolumn{8}{|c|}{ Flavones } \\
\hline 7 & 0.890 & 135 & 5 & + & 433 & 271 & Apigenin hexoside \\
\hline 9 & 0.924 & 140 & 35 & + & 287 & 153 & Luteolin * \\
\hline 22 & 4.615 & 80 & 30 & + & 271 & 153 & Apigenin * \\
\hline \multicolumn{8}{|c|}{ Isoflavones } \\
\hline 20 & 4.468 & 145 & 32 & - & 269 & 133 & Genistein \\
\hline \multicolumn{8}{|c|}{ Flavanones } \\
\hline 11 & 0.945 & 130 & 16 & - & 271 & 151 & Naringenin * \\
\hline \multicolumn{8}{|c|}{ Coumarins } \\
\hline 1 & 0.821 & 120 & 19 & - & 161 & 133 & $\begin{array}{c}\text { Umbelliferone } \\
\text { (7-hydroxycoumarin) }\end{array}$ \\
\hline 13 & 0.979 & 105 & 15 & - & 177 & 133 & Esculetin * \\
\hline 26 & 6.333 & 80 & 8 & - & 191 & 176 & Scopoletin * \\
\hline
\end{tabular}

* Identification confirmed using authentic standards.

Its presence in nettle leaves and stalks was reported previously by Pinelli et al. (2008) [6]. Compounds 5, 28, 30, 33 and $\mathbf{3 6}$ were identified as quercetin glycosides due to MS/MS ion at $\mathrm{m} / \mathrm{z} 303$ and were assigned as quercetin rhamnoside, quercetin pentoside, quercetin acetylhexoside, quercetin acetylrutinoside and quercetin pentosylhexoside due to fragmentation losses corresponding to rhamnose $(-146 \mathrm{amu})$, pentose $(-132 \mathrm{amu})$, hexose with acetyl residue ( -162 and $-42 \mathrm{amu})$, rutinose with acetyl residue $(-308$ and $-42 \mathrm{amu}$ ) and pentose with hexose moiety ( $-132 \mathrm{and}-162 \mathrm{amu}$ ) [38]. Previous reports on quercetin glycosides composition in nettle mostly included quercetin glucoside $[6,14,34]$ and quercetin rutinoside $[8,14,34]$, while not reporting the presence of acylated glycosides and diglycosides identified in this study. The latter provides the valuable contribution to detailed insight into nettle polyphenolic profile. Because of the characteristic fragment ion at $\mathrm{m} / \mathrm{z} 287$ corresponding to the kaempferol aglycon, compounds 6, 27, 29 and 39 were assigned as kaempferol hexoside, pentoside, rhamnoside and pentosylhexoside, respectively, due to fragment losses of corresponding sugar moieties. Similar to the previous literature reports on quercetin glycosides, the ones on kaempferol glycosides mostly only include kaempferol rutinoside [6,8] or glucoside [14,34,39], while not reporting the presence of kaempferol pentoside, rhamnoside and pentosylhexoside which are therefore being confirmed here for the first time. All compounds belonging to the class of flavan-3-ols (23, 37,38 and 40), namely epigallocatechingallate, epicatechin, catechin and epicatechingallate were identified and confirmed according to the authentic standard. Orčić et al. (2014) [14] identified catechin in nettle stalks, epicatechin was reported by Proestos et al. (2006) [40] in leaves, while there are no available reports on previous identification of epicatechingallate and epigallocatechingallate. Compounds 9 and 22 were assigned as luteolin and apigenin due to molecular ions at $m / z 287$ and $m / z 271$ and confirmed by comparison with standards, while compound 7 was tentatively identified as apigenin hexoside based on fragment ion at $m / z 271$ and fragmentation loss of -162 amu specific for hexose residue. Nencu et al. (2012) [41] reported the polyphenolic composition of nettle leaves including aglycones luteolin and apigenin, which is in accordance with our findings, while literature reports on flavone aglycones are scarce. Compound 20 showed precursor ion at $\mathrm{m} / \mathrm{z} 269$ and fragment ion at $m / z 133$, corresponding to the previously reported fragmentation mechanism of genistein anion [42], confirmed in nettle leaves extract by Zeković et al. (2017) [35]. Compounds 11, 13 and 26 were identified by its corresponding authentic standards as naringenin, esculetin and scopoletin, while compound $\mathbf{1}$ was tentatively assigned as umbelliferone due to molecular ion at $m / z 161$ and fragment ion at $m / z 133$ formed after the loss of one carbon 
monoxide molecule [43]. The composition of flavanones and coumarines reported in our study is in accordance with previous literature data $[14,34,35]$.

To examine the influence of phenological stage and habitat on the content of polyphenols in nettle leaves and stalks, identified polyphenols were arranged in corresponding classes, following which their individual concentrations accordingly summarized and subjected to statistical analysis, as shown in Table 3. Total polyphenols grand mean (GM)

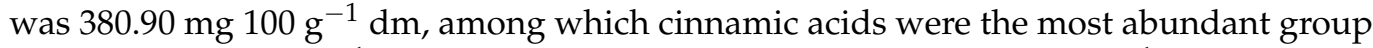

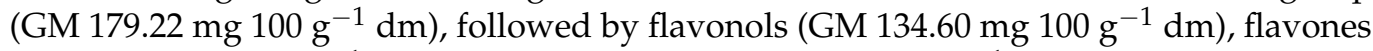

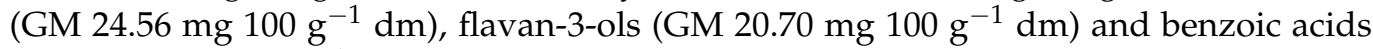

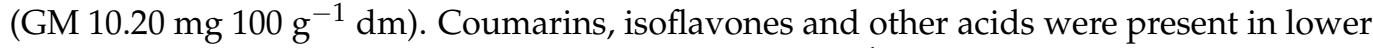

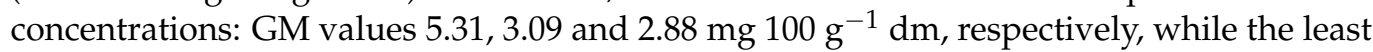

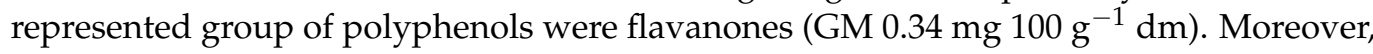
obtained results are in accordance with the results of other authors $[6,8,11,14]$, who reported quite similar phenolic profile in nettle extracts where cinnamic acids accounted for the most of presented total polyphenols.

As can be observed, the plant part, phenological stage and habitat had a significant influence $(p<0.01)$ on amounts of all polyphenols' groups. When comparing amounts of polyphenols between nettle leaves and stalks, it can be seen that leaves accumulated significantly higher concentrations of all polyphenols' groups (Table 3). Otles and Yalcin (2012) [7] also documented higher polyphenols content in wild nettle leaves extracts when compared to stalks extracts, as well as Pinelli et al. (2008) [6] who studied the content of polyphenols in cultivated and wild nettle and reported higher total polyphenols in leaves of both types of nettle (cultivated $7.364 \mathrm{mg} \mathrm{g}^{-1} \mathrm{fw}$, wild $2.58 \mathrm{mg} \mathrm{g}^{-1} \mathrm{fw}$ ) as opposed to nettle stalks (cultivated $3.670 \mathrm{mg} \mathrm{g}^{-1} \mathrm{fw}$, wild $0.750 \mathrm{mg} \mathrm{g}^{-1} \mathrm{fw}$ ).

Same authors documented the abundance of nettle stalks with fibers, consisting of several components of the lignin. However, in study of Orčić et al. (2014) [14], who examined nettle samples picked at three different locations, several identified polyphenols were recorded in higher levels in stalks, but the cinnamic acids presented in their study with chlorogenic acid were also more abundant in leaves.

Considering the phenological stage, it can be noticed that the 1st phenological stage (before flowering) resulted with higher concentrations of all polyphenols, except flavan-3ols which were significantly higher during the 2nd phenological stage (flowering) (Table 3). Overall, total polyphenols decreased for almost $50 \%$ by the 3 rd phenological stage. Similar to our results, in two studies of Nencu et al. $(2012,2013)[41,44]$, it was concluded that the optimal time for nettle leaves harvest was March, since the polyphenols content greatly decreased (over $80 \%$ ) by June and September, respectively. Authors reported that the total polyphenols decrease is due to the decrease of non-tannin phenols (phenolcarboxylic acids and flavonoids), which are the most important compounds from nettle leaves. This was also confirmed by Roslon et al. (2003) [45] who reported a sudden drop of phenolcarboxylic acids in leaves harvested at the plant flowering stage. Furthermore, the results of Biesiada et al. $(2009,2010)[46,47]$ and Kőszegi et al. (2020) [19] also indicated that the beginning of the nettle vegetation period was optimal for harvesting, giving the highest yield of polyphenols, which then decreased by autumn for over $50 \%$. Therefore, in order to obtain extracts with the highest polyphenols content, the optimal time to harvest the aerial parts of the nettle is spring (before the flowering of the plant). It can be assumed that the total polyphenols decrease starting at the flowering stage is a result of the physiological switch from the vegetative to the generative phase and the formation of flowers [48]. 
Table 3. The differences in polyphenols content $\left(\mathrm{mg} 100 \mathrm{~g}^{-1} \mathrm{dm}\right)$ in wild nettle (Urtica dioica L.) due to the plant part, phenological stage and habitat.

\begin{tabular}{|c|c|c|c|c|c|c|c|c|c|c|c|}
\hline \multicolumn{2}{|c|}{ Source of Variation } & $\begin{array}{l}\text { Benzoic } \\
\text { Acids }\end{array}$ & Cinnamic Acids & $\begin{array}{l}\text { Other } \\
\text { Acids }\end{array}$ & Flavonols & Flavan-3-ols & Flavones & Isoflavones & Flavanones & Coumarins & $\begin{array}{c}\text { Total } \\
\text { Polyphenols }\end{array}$ \\
\hline \multirow{3}{*}{\multicolumn{2}{|c|}{$\begin{array}{l}\text { Plant part } \\
\text { leaves } \\
\text { stalks }\end{array}$}} & $p<0.01 *$ & $p<0.01 *$ & $p<0.01 *$ & $p<0.01 *$ & $p<0.01 *$ & $p<0.01 *$ & $p<0.01 *$ & $p<0.01 *$ & $p<0.01 *$ & $p<0.01 *$ \\
\hline & & $12.55 \pm 0.04 \mathrm{~b}$ & $209.46 \pm 0.26 \mathrm{~b}$ & $4.30 \pm 0.03 \mathrm{~b}$ & $160.26 \pm 0.14 \mathrm{~b}$ & $25.99 \pm 0.04 \mathrm{~b}$ & $29.28 \pm 0.05 b$ & $3.37 \pm 0.02 \mathrm{~b}$ & $0.40 \pm 0.01 \mathrm{~b}$ & $6.53 \pm 0.01 b$ & $452.14 \pm 0.39 b$ \\
\hline & & $7.86 \pm 0.04 a$ & $148.98 \pm 0.26 a$ & $1.45 \pm 0.03 a$ & $108.94 \pm 0.14 \mathrm{a}$ & $15.42 \pm 0.04 \mathrm{a}$ & $19.84 \pm 0.05 \mathrm{a}$ & $2.81 \pm 0.02 \mathrm{a}$ & $0.29 \pm 0.01 \mathrm{a}$ & $4.09 \pm 0.01 \mathrm{a}$ & $309.67 \pm 0.39 a$ \\
\hline \multicolumn{2}{|c|}{ Phenological stage } & $p<0.01 *$ & $p<0.01 *$ & $p<0.01 *$ & $p<0.01 *$ & $p<0.01 *$ & $p<0.01 *$ & $p<0.01 *$ & $p<0.01 *$ & $p<0.01 *$ & $p<0.01 *$ \\
\hline \multicolumn{2}{|c|}{$\begin{array}{l}\text { 1st } \\
2 n d\end{array}$} & $12.65 \pm 0.05 c$ & $223.32 \pm 0.32 c$ & $3.66 \pm 0.03 c$ & $169.53 \pm 0.17 c$ & $22.23 \pm 0.05 b$ & $31.89 \pm 0.06 c$ & $3.70 \pm 0.02 c$ & $0.48 \pm 0.01 c$ & $7.28 \pm 0.02 c$ & $474.75 \pm 0.48 c$ \\
\hline \multirow{2}{*}{\multicolumn{2}{|c|}{$\begin{array}{l}\text { 2nd } \\
\text { 3rd }\end{array}$}} & $11.55 \pm 0.05 b$ & $202.70 \pm 0.32 b$ & $3.18 \pm 0.03 b$ & $141.72 \pm 0.17 \mathrm{~b}$ & $23.88 \pm 0.05 c$ & $22.28 \pm 0.06 \mathrm{~b}$ & $2.99 \pm 0.02 b$ & $0.33 \pm 0.01 b$ & $5.11 \pm 0.02 b$ & $413.75 \pm 0.48 b$ \\
\hline & & $6.42 \pm 0.05 a$ & $111.63 \pm 0.32 \mathrm{a}$ & $1.78 \pm 0.03 a$ & $92.54 \pm 0.17 \mathrm{a}$ & $16.00 \pm 0.05 a$ & $19.50 \pm 0.06 \mathrm{a}$ & $2.58 \pm 0.02 \mathrm{a}$ & $0.22 \pm 0.01 \mathrm{a}$ & $3.53 \pm 0.02 a$ & $254.21 \pm 0.48 \mathrm{a}$ \\
\hline \multicolumn{2}{|c|}{ Region/Habitat } & $p<0.01^{*}$ & $p<0.01 *$ & $p<0.01 *$ & $p<0.01^{*}$ & $p<0.01 *$ & $p<0.01^{*}$ & $p<0.01 *$ & $p<0.01 *$ & $p<0.01^{*}$ & $p<0.01 *$ \\
\hline \multirow{2}{*}{\multicolumn{2}{|c|}{$\begin{array}{l}\text { Žakanjska } \\
\text { Sopčić Vrh }\end{array}$}} & $12.06 \pm 0.10 \mathrm{~g}$ & $200.25 \pm 0.70 \mathrm{~h}$ & $2.10 \pm 0.07 \mathrm{~b}$ & $134.87 \pm 0.38 \mathrm{~g}$ & $16.68 \pm 0.11 b$ & $24.18 \pm 0.12 \mathrm{~g}$ & $2.92 \pm 0.05 \mathrm{~d}$ & $0.31 \pm 0.02 \mathrm{bcd}$ & $4.41 \pm 0.04 a$ & $397.78 \pm 1.03 \mathrm{~g}$ \\
\hline & Sopčić Vrh & $9.11 \pm 0.10 \mathrm{~cd}$ & $215.63 \pm 0.70 \mathrm{i}$ & $4.12 \pm 0.07 f$ & $150.83 \pm 0.38 \mathrm{i}$ & $26.97 \pm 0.11 \mathrm{i}$ & $26.69 \pm 0.12 h$ & $3.25 \pm 0.05 \mathrm{e}$ & $0.49 \pm 0.02 \mathrm{fg}$ & $5.20 \pm 0.04 d$ & $442.29 \pm 1.03 \mathrm{j}$ \\
\hline \multirow[t]{4}{*}{$\mathrm{C}$} & Žakanje & $19.39 \pm 0.10 \mathrm{i}$ & $227.10 \pm 0.70 \mathrm{j}$ & $2.56 \pm 0.07 c$ & $177.87 \pm 0.38 \mathrm{j}$ & $32.13 \pm 0.11 j$ & $42.44 \pm 0.12 j$ & $5.29 \pm 0.05 i$ & $0.41 \pm 0.02 \mathrm{def}$ & $5.92 \pm 0.04 f$ & $513.12 \pm 1.031$ \\
\hline & Zagreb I & $10.21 \pm 0.10 \mathrm{e}$ & $172.62 \pm 0.70 \mathrm{e}$ & $4.22 \pm 0.07 \mathrm{fg}$ & $130.21 \pm 0.38 \mathrm{f}$ & $15.63 \pm 0.11 a$ & $23.33 \pm 0.12 f$ & $1.95 \pm 0.05 a$ & $0.33 \pm 0.02 \mathrm{cde}$ & $6.76 \pm 0.04 \mathrm{~h}$ & $365.26 \pm 1.03 e$ \\
\hline & Zagreb II & $11.06 \pm 0.10 \mathrm{f}$ & $185.09 \pm 0.70 \mathrm{f}$ & $4.21 \pm 0.07 \mathrm{fg}$ & $125.81 \pm 0.38 \mathrm{~d}$ & $18.80 \pm 0.11 \mathrm{~cd}$ & $21.49 \pm 0.12 \mathrm{~d}$ & $3.47 \pm 0.05 \mathrm{ef}$ & $0.31 \pm 0.02 \mathrm{bcd}$ & $6.51 \pm 0.04 \mathrm{~g}$ & $376.74 \pm 1.03 \mathrm{f}$ \\
\hline & Koretići & $10.87 \pm 0.10 \mathrm{f}$ & $195.03 \pm 0.70 \mathrm{~g}$ & $4.53 \pm 0.07 \mathrm{gh}$ & $144.36 \pm 0.38 \mathrm{~h}$ & $22.09 \pm 0.11 \mathrm{~g}$ & $18.87 \pm 0.12 b$ & $3.77 \pm 0.05 \mathrm{~g}$ & $0.45 \pm 0.02 \mathrm{efg}$ & $5.06 \pm 0.04 \mathrm{~d}$ & $405.02 \pm 1.03 \mathrm{~h}$ \\
\hline \multirow{3}{*}{ M } & Ogulin & $13.18 \pm 0.10 \mathrm{~h}$ & $212.80 \pm 0.70 \mathrm{i}$ & $4.62 \pm 0.07 \mathrm{~h}$ & $182.65 \pm 0.38 \mathrm{k}$ & $20.88 \pm 0.11 \mathrm{f}$ & $36.09 \pm 0.12 \mathrm{i}$ & $3.51 \pm 0.05 f$ & $0.56 \pm 0.02 \mathrm{~g}$ & $6.77 \pm 0.04 \mathrm{~h}$ & $481.06 \pm 1.03 \mathrm{k}$ \\
\hline & Čovići I & $9.44 \pm 0.10 \mathrm{~cd}$ & $203.51 \pm 0.70 \mathrm{~h}$ & $3.73 \pm 0.07 \mathrm{e}$ & $152.62 \pm 0.38 \mathrm{i}$ & $19.69 \pm 0.11 \mathrm{e}$ & $23.92 \pm 0.12 \mathrm{fg}$ & $4.47 \pm 0.05 \mathrm{~h}$ & $0.44 \pm 0.02 \mathrm{efg}$ & $5.63 \pm 0.04 \mathrm{e}$ & $423.46 \pm 1.03 i$ \\
\hline & Čovići II & $8.96 \pm 0.10 c$ & $194.18 \pm 0.70 \mathrm{~g}$ & $3.08 \pm 0.07 d$ & $127.91 \pm 0.38 \mathrm{e}$ & $21.62 \pm 0.11 \mathrm{~g}$ & $17.14 \pm 0.12 a$ & $2.91 \pm 0.05 \mathrm{~d}$ & $0.53 \pm 0.02 \mathrm{~g}$ & $4.70 \pm 0.04 \mathrm{bc}$ & $381.01 \pm 1.03 \mathrm{f}$ \\
\hline \multirow{4}{*}{ S } & $\begin{array}{l}\text { Limski } \\
\text { zaliev }\end{array}$ & $9.53 \pm 0.10 \mathrm{~d}$ & $141.67 \pm 0.70 c$ & $1.07 \pm 0.07 \mathrm{a}$ & $111.21 \pm 0.38 b$ & $18.32 \pm 0.11 \mathrm{c}$ & $23.43 \pm 0.12 \mathrm{f}$ & $2.36 \pm 0.05 b$ & $0.23 \pm 0.02 \mathrm{abc}$ & $4.80 \pm 0.04 c$ & $312.61 \pm 1.03 c$ \\
\hline & Bale & $7.14 \pm 0.10 \mathrm{~b}$ & $143.55 \pm 0.70 c$ & $1.82 \pm 0.07 \mathrm{~b}$ & $114.39 \pm 0.38 c$ & $19.17 \pm 0.11 \mathrm{de}$ & $22.41 \pm 0.12 \mathrm{e}$ & $2.68 \pm 0.05 \mathrm{~cd}$ & $0.16 \pm 0.02 \mathrm{a}$ & $4.49 \pm 0.04 a$ & $315.81 \pm 1.03 \mathrm{~cd}$ \\
\hline & Vodnjan & $6.14 \pm 0.10 \mathrm{a}$ & $134.44 \pm 0.70 b$ & $1.03 \pm 0.07 a$ & $112.89 \pm 0.38 b c$ & $22.74 \pm 0.11 \mathrm{~h}$ & $22.13 \pm 0.12 \mathrm{e}$ & $2.35 \pm 0.05 b$ & $0.19 \pm 0.02 \mathrm{ab}$ & $5.15 \pm 0.04 \mathrm{~d}$ & $307.05 \pm 1.03 b$ \\
\hline & Muntrilj & $6.40 \pm 0.10 \mathrm{a}$ & $152.75 \pm 0.70 \mathrm{~d}$ & $1.87 \pm 0.07 \mathrm{~b}$ & $111.27 \pm 0.38 b$ & $18.72 \pm 0.11 \mathrm{~cd}$ & $21.06 \pm 0.12 \mathrm{~cd}$ & $2.46 \pm 0.05 b c$ & $0.22 \pm 0.02 \mathrm{abc}$ & $4.55 \pm 0.04 a b$ & $319.29 \pm 1.03 \mathrm{~d}$ \\
\hline \multicolumn{2}{|c|}{ Grand mean } & 10.20 & 179.22 & 2.88 & 134.60 & 20.70 & 24.56 & 3.09 & 0.34 & 5.31 & 380.90 \\
\hline
\end{tabular}

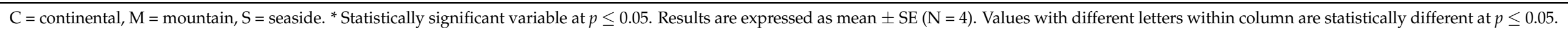


Habitats of wild nettle samples differed according to the climate conditions and could be grouped into three different regions: continental, mountain and seaside (Table 1). As presented in Table 3, habitats significantly $(p<0.01)$ differed regarding polyphenols content, with no uniform pattern regarding individual polyphenolic groups. Thus, Žakanje, belonging to the continental region, was characterized with the highest concentrations of total polyphenols $\left(513.12 \pm 1.03 \mathrm{mg} 100 \mathrm{~g}^{-1} \mathrm{dm}\right)$, benzoic $\left(19.39 \pm 0.10 \mathrm{mg} 100 \mathrm{~g}^{-1}\right.$ $\mathrm{dm})$ and cinnamic acids (227.10 $\left.\pm 0.70 \mathrm{mg} 100 \mathrm{~g}^{-1} \mathrm{dm}\right)$, flavan-3-ols (32.13 $\pm 0.11 \mathrm{mg}$ $\left.100 \mathrm{~g}^{-1} \mathrm{dm}\right)$, flavones $\left(42.44 \pm 0.12 \mathrm{mg} 100 \mathrm{~g}^{-1} \mathrm{dm}\right)$ and isoflavones $(5.29 \pm 0.05 \mathrm{mg}$ $\left.100 \mathrm{~g}^{-1} \mathrm{dm}\right)$. Contrarily, Ogulin, situated in mountain areas, was characterized with the highest amounts of other acids $\left(4.62 \pm 0.07 \mathrm{mg} 100 \mathrm{~g}^{-1} \mathrm{dm}\right)$, flavonols $(182.65 \pm 0.38 \mathrm{mg}$ $\left.100 \mathrm{~g}^{-1} \mathrm{dm}\right)$, flavanones $\left(0.56 \pm 0.02 \mathrm{mg} 100 \mathrm{~g}^{-1} \mathrm{dm}\right)$ and coumarins $(6.77 \pm 0.04 \mathrm{mg}$ $\left.100 \mathrm{~g}^{-1} \mathrm{dm}\right)$. Moreover, seaside habitats generally showed the lowest presence of all polyphenols. Still, based on total polyphenols content, a difference between seaside samples and ones from other two regions can be observed, where continental and mountain samples showed significantly higher levels of total polyphenols when compared to the samples from seaside zone. This could be explained as a plant's self-defense against oxidative stress caused by lower temperatures. According to Di Virgillo et al. (2015) [1] habitat greatly affects the accumulation of polyphenolic compounds in nettle. Just as in the current study, other authors also confirmed a diversity in nettle polyphenols content in growing areas $[7,14]$.

\subsection{Influence of Phenological Stage and Habitat on Pigments in Nettle Leaves and Stalks}

The presence of nettle natural color carriers, carotenoids and chlorophylls was monitored by HPLC analysis, which has detected a total of 13 carotenoids and 9 chlorophylls in wild nettle leaves and stalks, namely neoxanthin and its two derivatives, violaxanthin and its two derivatives, $13^{\prime}$-cis-lutein, lutein 5,6-epoxide, lutein, zeaxanthin, $9^{\prime}$-cis-lutein, $\alpha$-carotene, $\beta$-carotene, chlorophyll $a$ and its six derivatives and chlorophyll $b$ and its derivative (Figure 1, Supplementary file 1). A similar chlorophylls and carotenoids composition was previously reported [4,11]. For statistical purposes, identified pigments were grouped and analyzed as total carotenoids and total chlorophylls, as well as their sum (total pigments) (Table 4). Total pigments GM was $644.22 \mathrm{mg} 100 \mathrm{~g}^{-1} \mathrm{dm}$, most of which were chlorophylls (GM $611.19 \mathrm{mg} 100 \mathrm{~g}^{-1} \mathrm{dm}$ ), while carotenoids were less present (GM $33.03 \mathrm{mg} 100 \mathrm{~g}^{-1} \mathrm{dm}$ ). Other authors also reported higher chlorophylls content in nettle leaves extracts in comparison with the content of carotenoids $[9,11,47,49]$.

As presented in Table 4, all sources of variation significantly $(p<0.01)$ affected both groups of pigments as well as their sum. When comparing the pigments distribution in examined plant parts, abundance in pigments was expectedly higher in leaves since they are major photosynthesis organs [50]. Accordingly, Hojnik et al. (2007) [18] also reported a much higher concentration of chlorophylls in nettle leaves in comparison with stalks (147.1 vs. $16 \mathrm{mg} \mathrm{g}^{-1}$ extract). Furthermore, determined values for total chlorophylls in leaves were similar to previously reported results by Biesiada et al. (2010) [46], Zeipina et al. (2014) [49] and Repajić et al. (2020) [11], but were higher than in Đurović et al.'s (2017) [9] study. Also, the obtained total carotenoids content was in accordance with the values documented in Repajić et al.'s (2020) [11] study, but it showed dissimilarity in comparison with the data of other authors $[4,9,46,49]$, probably due to environmental differences. 


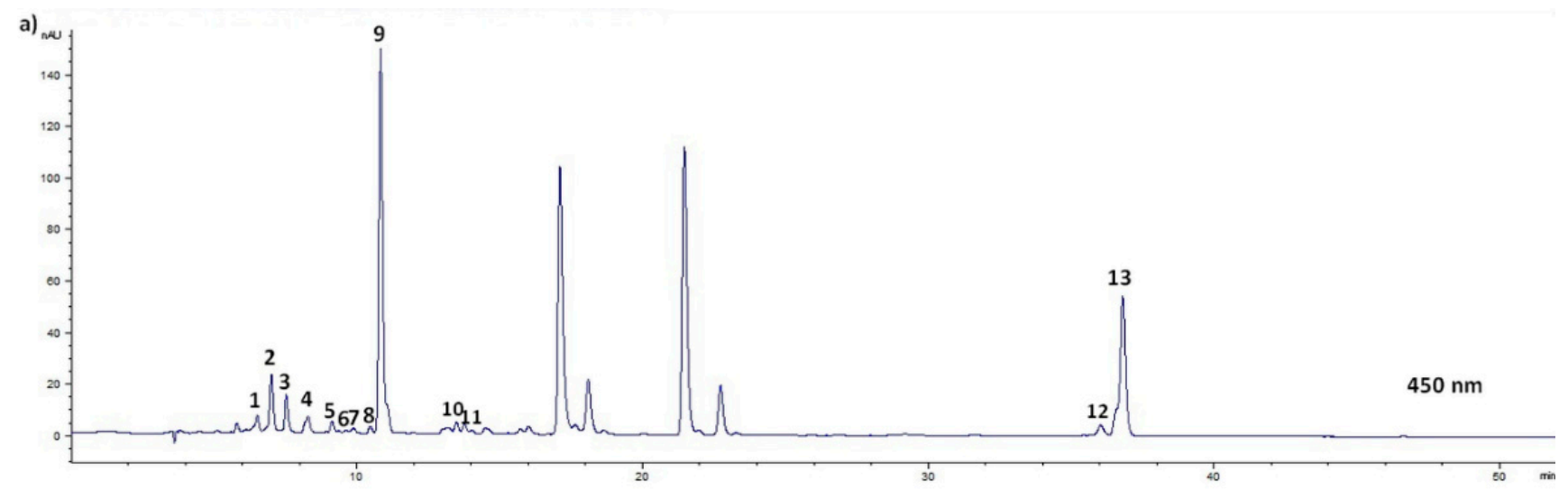

b)

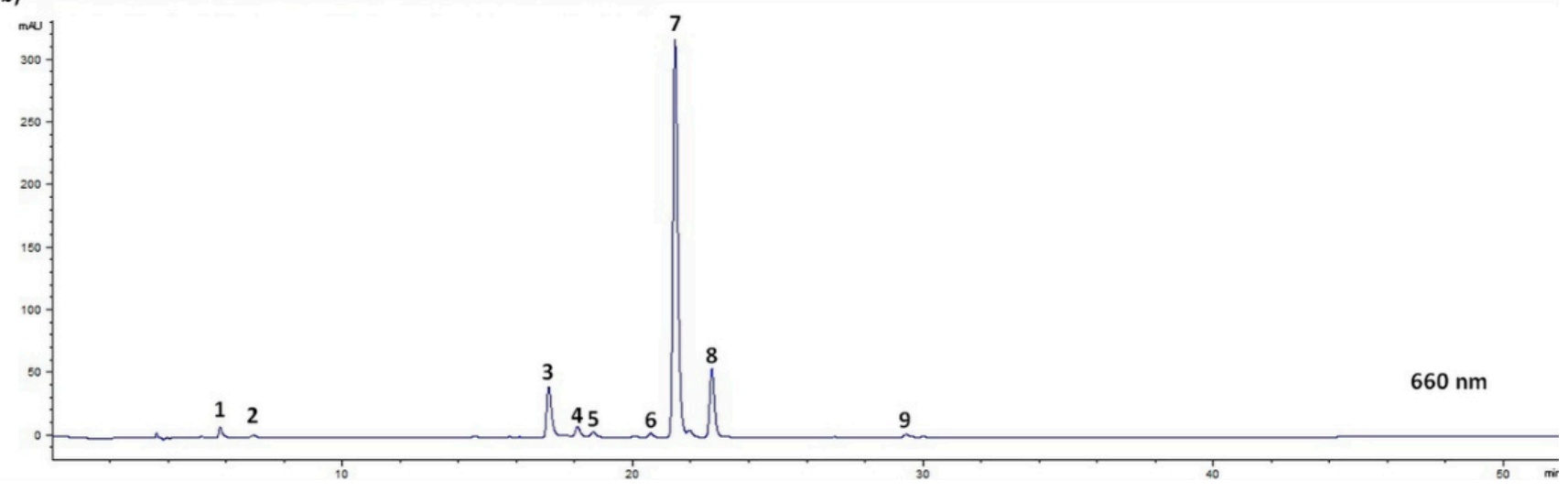

Figure 1. HPLC UV-VIS/PDA detection of pigments in wild nettle leaves (Urtica dioica L.) collected from Poreč before flowering: (a) at $450 \mathrm{~nm}(1=$ violaxanthin derivative 1, 2 = neoxanthin derivative 1, 3 = neoxanthin, $4=$ violaxanthin, 5 = violaxanthin derivative 2, $6=13^{\prime}$-cis-lutein, $7=$ neoxanthin derivative $2,8=$ lutein 5,6-epoxide, $9=$ lutein, $10=$ zeaxanthin, $11=9^{\prime}$-cis-lutein, $12=\alpha$-carotene, $13=\beta$-carotene $) ;(\mathbf{b})$ at $660 \mathrm{~nm}(1=$ chlorophyll $a$ derivative $1,2=$ chlorophyll $a$ derivative 2 , $3=$ chlorophyll $b, 4=$ chlorophyll $b$ derivative $1,5=$ chlorophyll $a$ derivative $3,6=$ chlorophyll $a$ derivative $4,7=$ chlorophyll $a$, $8=$ chlorophyll $a$ derivative 5, 9 = chlorophyll $a$ derivative 6 ).

Regarding the phenological stage, the highest amounts of all analyzed pigments were observed during the 2nd stage (flowering), where chlorophylls were the dominant

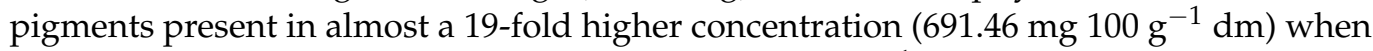
compared to the amount of carotenoids $\left(36.97 \mathrm{mg} 100 \mathrm{~g}^{-1} \mathrm{dm}\right)$. Similarly, Biesiada et al. (2009) [47] reported increased content of chlorophylls and carotenoids in nettle leaves when harvested in July in comparison with the harvest in May. Additionally, Marchetti et al. (2018) [10] observed that the highest lutein and $\beta$-carotene concentrations in nettle leaves occurred during the flowering stage (184 and $6.7 \mu \mathrm{g} \mathrm{g}^{-1} \mathrm{dm}$, respectively). Pajević et al. (1999) [51] also determined the maximum levels of chlorophylls and carotenoids in leaves of five alfalfa (Medicago sativa L.) genotypes just before and during the flowering stage. These similar patterns can be explained by enhanced production of secondary metabolites, such as plant pigments, during the flowering stage as a plant mechanism for fulfilling important physiological tasks like attracting pollinators [20].

When observing the differences in nettle pigments among the examined habitats, generally samples grown in seaside regions (particularly in the Limski zaljev and Bale habitats) had the highest pigments content. As this area was generally characterized by higher temperatures and lower accumulated precipitation (Table 1), these results are expected since the level of pigments in nettle is influenced by environmental factors, primarily the climate and growing location, where exposure to higher temperatures and more solar energy will result in a higher pigments content [24]. The results of Candido et al.'s (2015) [52] study, in which they examined carotenoid content in buriti palms pulp grown in two different regions (Amazon and Cerrado, Brazil), supported the aforementioned 
results. They concluded that a higher content of carotenoids was measured in samples from the Amazon area, characterized by higher temperatures and humidity which prevent photodegradation of fruit pigments.

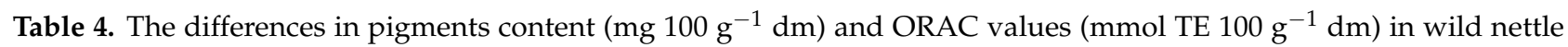
(Urtica dioica L.) upon plant part, phenological stage and habitat.

\begin{tabular}{|c|c|c|c|c|c|}
\hline \multicolumn{2}{|c|}{ Source of Variation } & Carotenoids & Chlorophylls & Total Pigments & ORAC \\
\hline \multicolumn{2}{|c|}{ Plant Part } & $p<0.01^{*}$ & $p<0.01 *$ & $p<0.01 *$ & $p<0.01 *$ \\
\hline \multicolumn{2}{|c|}{ leaves } & $61.46 \pm 0.08 b$ & $1126.94 \pm 0.66 \mathrm{~b}$ & $1188.40 \pm 0.71 b$ & $11.96 \pm 0.02 b$ \\
\hline \multicolumn{2}{|c|}{ stalks } & $4.60 \pm 0.08 \mathrm{a}$ & $95.45 \pm 0.66 a$ & $100.05 \pm 0.71 \mathrm{a}$ & $7.37 \pm 0.02 \mathrm{a}$ \\
\hline \multicolumn{2}{|c|}{ Phenological Stage } & $p<0.01 *$ & $p<0.01 *$ & $p<0.01 *$ & $p<0.01 *$ \\
\hline \multicolumn{2}{|c|}{ 1st } & $32.49 \pm 0.10 \mathrm{~b}$ & $589.07 \pm 0.81 b$ & $621.56 \pm 0.86 b$ & $11.26 \pm 0.04 b$ \\
\hline \multicolumn{2}{|c|}{ 2nd } & $36.97 \pm 0.10 c$ & $691.46 \pm 0.81 c$ & $728.44 \pm 0.86 c$ & $12.10 \pm 0.04 \mathrm{c}$ \\
\hline \multicolumn{2}{|c|}{$3 r d$} & $29.64 \pm 0.10 \mathrm{a}$ & $553.04 \pm 0.81 \mathrm{a}$ & $582.67 \pm 0.86 a$ & $5.63 \pm 0.04 a$ \\
\hline \multicolumn{2}{|c|}{ Region/Habitat } & $p<0.01 *$ & $p<0.01 *$ & $p<0.01 *$ & $p<0.01 *$ \\
\hline \multirow{6}{*}{$\mathrm{C}$} & Sela Žakanjska & $37.29 \pm 0.21 \mathrm{~h}$ & $701.89 \pm 1.76 \mathrm{~g}$ & $739.18 \pm 1.87 \mathrm{~h}$ & $11.76 \pm 0.06 \mathrm{i}$ \\
\hline & Sopčić Vrh & $31.95 \pm 0.21 \mathrm{~d}$ & $558.11 \pm 1.76 c$ & $590.06 \pm 1.87 \mathrm{~d}$ & $11.78 \pm 0.06 \mathrm{j}$ \\
\hline & Žakanje & $27.94 \pm 0.21 c$ & $466.84 \pm 1.76 a$ & $494.78 \pm 1.87 a$ & $12.25 \pm 0.06 \mathrm{~m}$ \\
\hline & Zagreb I & $26.70 \pm 0.21 b$ & $480.27 \pm 1.76 b$ & $506.97 \pm 1.87 \mathrm{~b}$ & $11.89 \pm 0.06 \mathrm{k}$ \\
\hline & Zagreb II & $32.14 \pm 0.21 \mathrm{~d}$ & $600.73 \pm 1.76 \mathrm{~d}$ & $632.87 \pm 1.87 \mathrm{e}$ & $9.46 \pm 0.06 f$ \\
\hline & Koretići & $31.81 \pm 0.21 \mathrm{~d}$ & $596.83 \pm 1.76 \mathrm{~d}$ & $628.64 \pm 1.87 \mathrm{e}$ & $11.22 \pm 0.06 \mathrm{~h}$ \\
\hline \multirow{3}{*}{ M } & Ogulin & $33.23 \pm 0.21 \mathrm{e}$ & $598.67 \pm 1.76 \mathrm{~d}$ & $631.91 \pm 1.87 \mathrm{e}$ & $12.20 \pm 0.061$ \\
\hline & Čovići I & $25.65 \pm 0.21 \mathrm{a}$ & $472.09 \pm 1.76 \mathrm{ab}$ & $497.74 \pm 1.87 a$ & $10.59 \pm 0.06 \mathrm{~g}$ \\
\hline & Čovići II & $34.29 \pm 0.21 f$ & $650.39 \pm 1.76 \mathrm{e}$ & $684.68 \pm 1.87 f$ & $9.46 \pm 0.06 f$ \\
\hline \multirow{5}{*}{ S } & Poreč & $27.40 \pm 0.21 b c$ & $552.88 \pm 1.76 c$ & $580.28 \pm 1.87 c$ & $6.28 \pm 0.06 b$ \\
\hline & Limski zaljev & $40.21 \pm 0.21 j$ & $719.69 \pm 1.76 h$ & $759.90 \pm 1.87 i$ & $6.26 \pm 0.06 a$ \\
\hline & Bale & $38.35 \pm 0.21 \mathrm{i}$ & $760.95 \pm 1.76 \mathrm{i}$ & $799.30 \pm 1.87 j$ & $6.58 \pm 0.06 c$ \\
\hline & Vodnjan & $35.93 \pm 0.21 \mathrm{~g}$ & $678.67 \pm 1.76 f$ & $714.60 \pm 1.87 \mathrm{~g}$ & $8.08 \pm 0.06 \mathrm{e}$ \\
\hline & Muntrilj & $39.55 \pm 0.21 \mathrm{j}$ & $718.67 \pm 1.76 h$ & $758.23 \pm 1.87 \mathrm{i}$ & $7.52 \pm 0.06 \mathrm{~d}$ \\
\hline \multicolumn{2}{|c|}{ Grand mean } & 33.03 & 611.19 & 644.22 & 9.67 \\
\hline
\end{tabular}

$\mathrm{C}=$ continental, $\mathrm{M}=$ mountain, $\mathrm{S}=$ seaside. ${ }^{*}$ Statistically significant variable at $p \leq 0.05$. Results are expressed as mean $\pm \mathrm{SE}(\mathrm{N}=4)$. Values with different letters within column are statistically different at $p \leq 0.05$.

\subsection{Influence of Phenological Stage and Habitat on Antioxidant Capacity in Nettle Leaves and Stalks}

The results of nettle antioxidant capacity measured by the ORAC method are given in Table 4 and Supplementary file 1 . ORAC GM was $9.67 \mathrm{mmol} \mathrm{TE} 100 \mathrm{~g}^{-1} \mathrm{dm}$. Moreover, the nettle antioxidant capacity was significantly influenced $(p<0.01)$ by all examined sources of variation. Nettle leaves showed higher antioxidant capacity in comparison with stalks (11.96 mmol TE $100 \mathrm{~g}^{-1} \mathrm{dm}$ vs. $7.37 \mathrm{mmol} \mathrm{TE} 100 \mathrm{~g}^{-1} \mathrm{dm}$ ). Similar ORAC values in nettle leaves were recorded in study of Repajić et al. (2020) [11], while Česlova et al. (2016) [53] obtained the same results by measuring the antioxidant capacity of different nettle parts infusions, where nettle leaves gained higher DPPH levels when compared to stalks. In support, Kirca and Arslan (2008) [54] concluded that leaves and flowers of different examined plants had a higher antioxidant capacity when compared to stalks and seeds.

When observing the influence of phenological stage, the highest ORAC value was observed during flowering, after which it significantly decreased and was the lowest after flowering. Similar to the results of the current study, other authors $[19,46]$ documented that the antioxidant capacity of nettle leaves was higher in the earliest periods (April/May and June/July), after which it decreased (September/October).

Nettle samples showed diversity in antioxidant capacity upon habitat variations. As can be observed, samples from the continental and mountain part were described with the highest ORAC levels as opposed to nettles grown in seaside areas, which were 
characterized with the lowest antioxidant capacity levels. These results are in accordance with previously discussed contents of polyphenols and pigments, where a certain grouping of the samples according to the presence of polyphenols and pigments by the growing area is evident. Moreover, calculated correlation coefficients supported this observation, since they showed a strong correlation between ORAC values and cinnamic acids, flavonols and total phenols (Table 5).

Table 5. Pearson's correlations between analyzed compounds $\left(\mathrm{mg} 100 \mathrm{~g}^{-1} \mathrm{dm}\right)$ and ORAC values (mmol TE $100 \mathrm{~g}^{-1} \mathrm{dm}$ ).

\begin{tabular}{cc}
\hline Group of Compounds & ORAC Value \\
\hline Benzoic acids & $0.53^{*}$ \\
Cinnamic acids & $0.71^{*}$ \\
Other acids & $0.59^{*}$ \\
Flavonols & $0.68^{*}$ \\
Flavan-3-ols & $0.47^{*}$ \\
Flavones & $0.36^{*}$ \\
Isoflavones & $0.36^{*}$ \\
Flavanones & $0.39^{*}$ \\
Coumarins & $0.60^{*}$ \\
Total phenols & $0.71^{*}$ \\
Carotenoids & $0.46^{*}$ \\
Chlorophylls & $0.44^{*}$ \\
Total pigments & $0.44^{*}$ \\
\hline
\end{tabular}

${ }^{*} p \leq 0.05$.

Obtained results clearly demonstrated the importance of the appropriate plant part selection as well as its phenological stage with the presence of the highest bioactive compounds accumulation in order to obtain the maximally enriched product, which will be beneficial for consumers.

\subsection{PCA Analysis}

Additionally, in order to examine a possible grouping of the nettle samples according to the applied sources of variations, PCA was carried out and obtained results are presented in Figure 2.

According to the preliminary PCA, a communality value of $\geq 0.5$ described all 14 variables, thus they were all included in the test. The first two components (PC1 and PC2) explained $71.31 \%$ of total variance, where PC1 accounted for $53.47 \%$ of total variance, while PC2 attributed to $17.84 \%$ of total variance. Since PC1 strongly/very strongly negatively correlated $(-0.77 \leq \mathrm{r} \leq-0.96)$ with benzoic and cinnamic acids, flavonols, flavan-3-ols, flavones, ORAC values and total polyphenols, while PC2 had a strong/very strong correlation with carotenoids, chlorophylls and total pigments $(-0.79 \leq \mathrm{r} \leq-0.81)$, these variables could be considered as the most discriminating variables.

As can be seen in Figure 2a, separation of the samples clearly occurs based on the plant part. Most of the leaf samples were distributed at negative PC2 values, while all samples of stalks were situated at positive PC2 values. Regarding the phenological stage, a certain grouping appeared between samples from the 1st and 3rd phenological stage, where samples collected before flowering were mainly situated at negative PC1 values and almost all of the post-flowering samples were located at the positive PC1 values (Figure 2b). a partial grouping of nettle samples is visible in Figure 2c based on the growing region, where the most of separation can be seen to be present between continental and seaside samples, although this did not completely occur. 

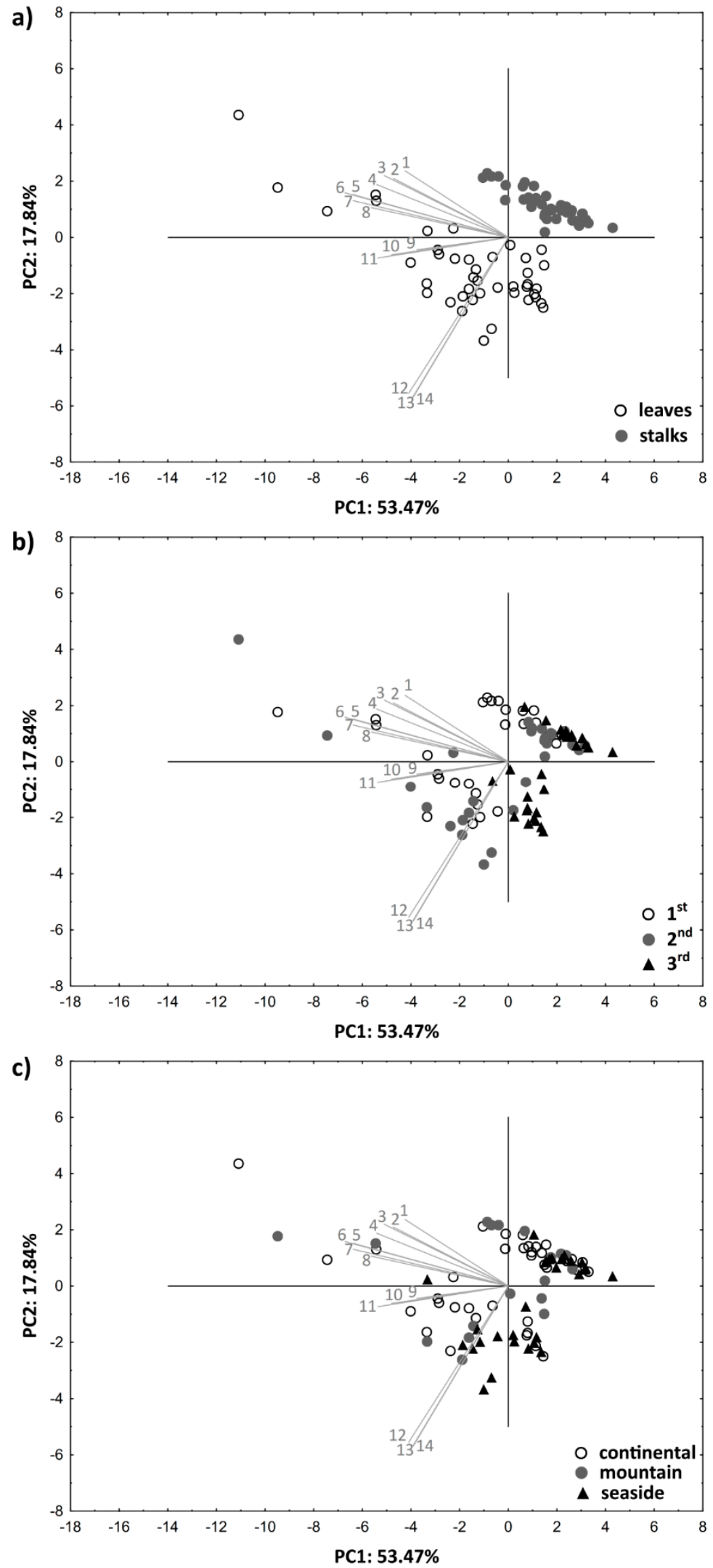

Figure 2. Distribution of wild nettle samples in two-dimensional coordinate system defined by the first two principal components (PC1 and PC2) according to the (a) plant part; (b) phenological stage; (c) growing region ( 1 = isoflavones, 2 = flavanones, 3 = flavones, $4=$ benzoic acids, $5=$ cinnamic acids, $6=$ total polyphenols, $7=$ flavonols, $8=$ flavan-3-ols, $9=$ other acids, $10=$ coumarins, $11=$ ORAC, $12=$ carotenoids, $13=$ chlorophylls, $14=$ total pigments $)$. 


\section{Conclusions}

The current study confirmed the abundance of wild nettle with diverse bioactive molecules such as low molecular weight polyphenols and pigments, where 41 phenolic compounds, 13 carotenoids and 9 chlorophylls were documented. By using applied extraction conditions, cinnamic acids and flavonols were found to be the dominant classes of identified polyphenols (33.10-519.81 mg $100 \mathrm{~g}^{-1} \mathrm{dm}$ and $57.44-383.25 \mathrm{mg} 100 \mathrm{~g}^{-1} \mathrm{dm}$, respectively), while chlorophylls were the most abundant natural pigments (4.26-1934.38 mg $100 \mathrm{~g}^{-1} \mathrm{dm}$ ). Moreover, the ORAC values of obtained nettle extracts ranged from 3.05 to $19.83 \mathrm{mmol} \mathrm{TE} 100 \mathrm{~g}^{-1} \mathrm{dm}$. However, in order to obtain high valuable wild nettle extracts that are abundant in natural antioxidants, it is of the utmost importance to select appropriate plant parts as well as an appropriate harvest time. Obtained results evidenced that the highest levels of nettle bioactives accompanied by high antioxidant capacity were present in leaves, which should be collected during the early phenological period (before and at the flowering stage). Moreover, the amounts of wild nettle polyphenols and pigments greatly differed based on the natural habitat, as samples from the seaside region were characterized with elevated accumulation of pigments, while higher polyphenols amounts were present in habitats located in continental and mountain areas. This research will surely contribute to the selection of plant part and phenological stage for nettle optimal harvest, as well as to designate nettle natural habitats that have been shown to be a source of valuable plant material. These findings present the basis for the production of nettle seedlings with high bioactives content, which could further be used in the production of liquid and dry extracts. Furthermore, they showed the importance of a multidisciplinary approach for the selection of a plant part as well as its phenological stage in order to provide highly enriched products intended for the benefit of consumers.

In addition, besides low molecular weight polyphenols and pigments covered by this research, future studies could also include other beneficial compounds present in nettle such as oligomers and polymers as well as sterols, to provide a full insight into the nettle's bioactive potential.

Supplementary Materials: The following figures and tables are available online at https:/ /www. mdpi.com/2304-8158/10/1/190/s1, (file 1) Figure S1: LC-MS/MS chromatogram in dMRM acquisition from the extract of wild nettle leaves (Urtica dioica L.) collected from Poreč before flowering, (file 2) Tables S1-S3: Concentrations of individual compounds and ORAC values in nettle (Urtica dioica L.) samples.

Author Contributions: Conceptualization, M.R.; Data curation, M.R., Z.Z., S.P. and I.E.G.; Formal analysis, M.R., E.C., Z.Z. and S.P.; Methodology, M.R. and I.E.G.; Project administration, V.D.-U.; Resources, S.R. and I.P.; Supervision, M.R. and V.D.-U.; Visualization, M.R.; Writing—original draft, M.R., E.C. and I.E.G.; Writing—review \& editing, M.R., S.P., I.E.G., S.R., I.P. and V.D.-U. All authors have read and agreed to the published version of the manuscript.

Funding: This research was funded by the Croatian Science Foundation project, grant number IP-01-2018-4924.

Acknowledgments: Authors wish to thank Valentina Kruk from mag.ing.techn.aliment for her assistance during experimental work and the Meteorological and Hydrological Institute of Croatia for providing the meteorological data.

Conflicts of Interest: The authors declare no conflict of interest. The funders had no role in the design of the study; in the collection, analyses, or interpretation of data; in the writing of the manuscript, or in the decision to publish the results.

\section{References}

1. Di Virgilio, N.; Papazoglou, E.G.; Jankauskiene, Z.; Di Lonardo, S.; Praczyk, M.; Wielgusz, K. The potential of stinging nettle (Urtica dioica L.) as a crop with multiple uses. Ind. Crop. Prod. 2015, 68, 42-49. [CrossRef]

2. Kregiel, D.; Pawlikowska, E.; Antolak, H. Urtica spp.: Ordinary plants with extraordinary properties. Molecules 2018, $23,1664$. [CrossRef] [PubMed]

3. Upton, R. Stinging nettles leaf (Urtica dioica L.): Extraordinary vegetable medicine. J. Herb. Med. 2013, 3, 9-38. [CrossRef] 
4. Guil-Guerrero, J.L.; Rebolloso-Fuentes, M.M.; Isasa, M.E.T. Fatty acids and carotenoids from Stinging Nettle (Urtica dioica L.). J. Food Compos. Anal. 2003, 16, 111-119. [CrossRef]

5. Sajfrtová, M.; Sovová, H.; Opletal, L.; Bártlová, M. Near-critical extraction of $\beta$-sitosterol and scopoletin from stinging nettle roots. J. Supercrit. Fluids 2005, 35, 111-118. [CrossRef]

6. Pinelli, P.; Ieri, F.; Vignolini, P.; Bacci, L.; Baronti, S.; Romani, A. Extraction and HPLC analysis of phenolic compounds in leaves, stalks, and textile fibers of Urtica dioica L. J. Agric. Food Chem. 2008, 56, 9127-9132. [CrossRef]

7. Otles, S.; Yalcin, B. Phenolic compounds analysis of root, stalk, and leaves of nettle. Sci. World J. 2012, 2012. [CrossRef]

8. Carvalho, A.R.; Costa, G.; Figueirinha, A.; Liberal, J.; Prior, J.A.V.; Lopes, M.C.; Cruz, M.T.; Batista, M.T. Urtica spp.: Phenolic composition, safety, antioxidant and anti-inflammatory activities. Food Res. Int. 2017, 99, 485-494. [CrossRef]

9. Đurović, S.; Pavlić, B.; Šorgić, S.; Popov, S.; Savić, S.; Pertonijević, M.; Radojković, M.; Cvetanović, A.; Zeković, Z. Chemical composition of stinging nettle leaves obtained by different analytical approaches. J. Funct. Foods 2017, 32, 18-26. [CrossRef]

10. Marchetti, N.; Bonetti, G.; Brandolini, V.; Cavazzini, A.; Maietti, A.; Meca, G.; Mañes, J. Stinging nettle (Urtica dioica L.) as a functional food additive in egg pasta: Enrichment and bioaccessibility of Lutein and $\beta$-carotene. J. Funct. Foods 2018, 47, 547-553. [CrossRef]

11. Repajić, M.; Cegledi, E.; Kruk, V.; Pedisić, S.; Çınar, F.; Bursać Kovačević, D.; Žutić, I.; Dragović-Uzelac, V. Accelerated Solvent Extraction as a Green Tool for the Recovery of Polyphenols and Pigments from Wild Nettle Leaves. Processes 2020, 8, 803. [CrossRef]

12. Dhouibi, R.; Affes, H.; Salem, M.B.; Hammami, S.; Sahnoun, Z.; Zeghal, K.M.; Ksouda, K. Screening of pharmacological uses of Urtica dioica and others benefits. Prog. Biophys. Mol. Biol. 2020, 150, 67-77. [CrossRef] [PubMed]

13. Wagner, H.; Willer, F.; Samtleben, R.; Boos, G. Search for the antiprostatic principle of stinging nettle (Urtica dioica) roots. Phytomedicine 1994, 1, 213-224. [CrossRef]

14. Orcic, D.; Franciškovic, M.; Bekvalac, K.; Svircev, E.; Beara, I.; Lesjak, M.; Mimica-Dukic, N. Quantitative determination of plant phenolics in Urtica dioica extracts by high-performance liquid chromatography coupled with tandem mass spectrometric detection. Food Chem. 2014, 143, 48-53. [CrossRef] [PubMed]

15. Chrubasik, J.E.; Roufogalis, B.D.; Wagner, H.; Chrubasik, S. A comprehensive review on the stinging nettle effect and efficacy profiles. Part II: Urticae radix. Phytomedicine 2007, 14, 568-579. [CrossRef] [PubMed]

16. Brown, D. Encyclopedia of herbs and their uses. In Encyclopedia of Common Natural Ingredients Used in Food, Drugs, and Cosmetics; Leung, Y.A., Foster, S., Eds.; Wiley: Hoboken, NJ, USA, 1995.

17. Mottaleb, M.A.; Sarker, S.D. Accelerated solvent extraction for natural products isolation. In Natural Products Isolation; Springer: Berlin/Heidelberg, Germany, 2012; pp. 75-87.

18. Hojnik, M.; Škerget, M.; Knez, Ž. Isolation of chlorophylls from stinging nettle (Urtica dioica L.). Sep. Purif. Technol. 2007, 57, 37-46. [CrossRef]

19. Kőszegi, K.; Békássy-Molnár, E.; Koczka, N.; Kerner, T.; Stefanovits-Bányai, É. Changes in Total Polyphenol Content and Antioxidant Capacity of Stinging Nettle (Urtica dioica L.) from Spring to Autumn. Period. Polytech. Chem. Eng. 2020, 64, 548-554. [CrossRef]

20. Ncube, B.; Van Staden, J. Tilting plant metabolism for improved metabolite biosynthesis and enhanced human benefit. Molecules 2015, 20, 12698-12731. [CrossRef]

21. Moore, M. Medicinal Plants of the Mountain West; Museum of New Mexico Press: Santa Fe, NM, USA, 2003 ; ISBN 0890134545.

22. Tolić, M.T.; Krbavčić, I.P.; Vujević, P.; Milinović, B.; Jurčević, I.L.; Vahčić, N. Effects of weather conditions on phenolic content and antioxidant capacity in juice of chokeberries (Aronia melanocarpa L.). Pol. J. Food Nutr. Sci. 2017, 67, 67-74. [CrossRef]

23. González-Talice, J.; Yuri, J.A.; del Pozo, A. Relations among pigments, color and phenolic concentrations in the peel of two Gala apple strains according to canopy position and light environment. Sci. Hortic. 2013, 151, 83-89. [CrossRef]

24. Saini, R.K.; Nile, S.H.; Park, S.W. Carotenoids from fruits and vegetables: Chemistry, analysis, occurrence, bioavailability and biological activities. Food Res. Int. 2015, 76, 735-750. [CrossRef] [PubMed]

25. AOAC. Official Methods of Analysis: Changes in Official Methods of Analysis Made at the Annual Meeting. Supplement; Association of Official Analytical Chemists: Rockville, MD, USA, 1990; Volume 15.

26. Elez Garofulić, I.; Zorić, Z.; Pedisić, S.; Brnčić, M.; Dragović-Uzelac, V. UPLC-MS2 Profiling of Blackthorn Flower Polyphenols Isolated by Ultrasound-Assisted Extraction. J. Food Sci. 2018, 83, 2782-2789. [CrossRef] [PubMed]

27. Castro-Puyana, M.; Pérez-Sánchez, A.; Valdés, A.; Ibrahim, O.H.M.; Suarez-Álvarez, S.; Ferragut, J.A.; Micol, V.; Cifuentes, A.; Ibáñez, E.; García-Cañas, V. Pressurized liquid extraction of Neochloris oleoabundans for the recovery of bioactive carotenoids with anti-proliferative activity against human colon cancer cells. Food Res. Int. 2017, 99, 1048-1055. [CrossRef] [PubMed]

28. Sozgen Baskan, K.; Tutem, E.; Ozer, N.; Apak, R. Spectrophotometric and chromatographic assessment of contributions of carotenoids and chlorophylls to the total antioxidant capacities of plant foods. J. Agric. Food Chem. 2013, 61, 11371-11381. [CrossRef]

29. Gupta, P.; Sreelakshmi, Y.; Sharma, R. A rapid and sensitive method for determination of carotenoids in plant tissues by high performance liquid chromatography. Plant Methods 2015, 11, 5. [CrossRef]

30. Prior, R.L.; Wu, X.; Schaich, K. Standardized methods for the determination of antioxidant capacity and phenolics in foods and dietary supplements. J. Agric. Food Chem. 2005, 53, 4290-4302. [CrossRef] 
31. Bender, C.; Graziano, S.; Zimmerman, B.F.; Weidlich, H.H. Antioxidant potential of aqueous plant extracts assessed by the cellular antioxidant activity assay. Am. J. Biol. Life Sci. 2014, 2, 72-79.

32. Gruz, J.; Novák, O.; Strnad, M. Rapid analysis of phenolic acids in beverages by UPLC-MS/MS. Food Chem. 2008, 111, 789-794. [CrossRef]

33. Parejo, I.; Jauregui, O.; Sánchez-Rabaneda, F.; Viladomat, F.; Bastida, J.; Codina, C. Separation and characterization of phenolic compounds in fennel (Foeniculum vulgare) using liquid chromatography-negative electrospray ionization tandem mass spectrometry. J. Agric. Food Chem. 2004, 52, 3679-3687. [CrossRef]

34. Francišković, M.; Gonzalez-Pérez, R.; Orčić, D.; de Medina, F.S.; Martínez-Augustin, O.; Svirčev, E.; Simin, N.; Mimica-Dukić, N. Chemical Composition and Immuno-Modulatory Effects of Urtica dioica L. (Stinging Nettle) Extracts. Phyther. Res. 2017, 31, 1183-1191. [CrossRef]

35. Zeković, Z.; Cvetanović, A.; Švarc-Gajić, J.; Gorjanović, S.; Sužnjević, D.; Mašković, P.; Savić, S.; Radojković, M.; Đurović, S. Chemical and biological screening of stinging nettle leaves extracts obtained by modern extraction techniques. Ind. Crop. Prod. 2017, 108, 423-430. [CrossRef]

36. Chen, Y.; Yu, H.; Wu, H.; Pan, Y.; Wang, K.; Jin, Y.; Zhang, C. Characterization and Quantification by LC-MS/MS of the Chemical Components of the Heating Products of the Flavonoids Extract in Pollen Typhae for Transformation Rule Exploration. Molecules 2015, 20, 18352-18366. [CrossRef] [PubMed]

37. Bucar, F.; Britzmann, B.; Streit, B.; Weigend, M. LC-PDA-MS-profiles of phenolic compounds in extracts of aerial parts of Urtica species. Planta Med. 2006, 72. [CrossRef]

38. Pinheiro, P.F.; Justino, G.C. Structural Analysis of Flavonoids and Related Compounds-A Review of Spectroscopic Applications. In Phytochemicals - A Global Perspective of Their Role in Nutrition and Health; Rao, V., Ed.; InTech: Rijeka, Croatia, $2012 ;$ pp. 33-56.

39. Farag, M.A.; Weigend, M.; Luebert, F.; Brokamp, G.; Wessjohann, L.A. Phytochemical, phylogenetic, and anti-inflammatory evaluation of 43 Urtica accessions (stinging nettle) based on UPLC-Q-TOF-MS metabolomic profiles. Phytochemistry 2013, 96, 170-183. [CrossRef] [PubMed]

40. Proestos, C.; Boziaris, I.S.; Nychas, G.-J.; Komaitis, M. Analysis of flavonoids and phenolic acids in Greek aromatic plants: Investigation of their antioxidant capacity and antimicrobial activity. Food Chem. 2006, 95, 664-671. [CrossRef]

41. Nencu, I.; Vlase, L.; Istudor, V.; Duţu, L.E.; Gird, C.E. Preliminary research regarding the therapeutic uses of Urtica dioica L. Note I. The polyphenols evaluation. Farmacia 2012, 60, 493-500.

42. Wang, F.; Jiang, K.; Li, Z. Purification and Identification of Genistein in Ginkgo biloba Leaf Extract. Chin. J. Chromatogr. 2007, 25, 509-513. [CrossRef]

43. Mazimba, O. Umbelliferone: Sources, chemistry and bioactivities review. Bull. Fac. Pharm. Cairo Univ. 2017, 55, 223-232. [CrossRef]

44. Ioana, N.; Viorica, I.; Diana-Carolina, I.; Valeria, R. Preliminary research regarding the therapeutic uses of Urtica dioica 1 note ii. The dynamics of accumulation of total phenolic compounds and ascorbic acid. Farmacia 2013, 61, $276-283$.

45. Roslon, W.; Weglarz, Z. Polyphenolic acids of female and male forms of Urtica dioica. In Proceedings of the International Conference on Medicinal and Aromatic Plants (Part II), Budapest, Hungary, 8-11 July 2001; pp. 101-104.

46. Biesiada, A.; Kucharska, A.; Sokół-Łętowska, A.; Kuś, A. Effect of the Age of Plantation and Harvest Term on Chemical Composition and Antioxidant Avctivity of Stinging Nettle (Urtica dioica L.). Ecol. Chem. Eng. A 2010, 17, $1061-1068$.

47. Biesiada, A.; Wołoszczak, E.; Sokół-Łętowska, A.; Kucharska, A.Z.; Nawirska-Olszańska, A. The effect of nitrogen form and dose on yield, chemical composition and antioxidant activity of stinging nettle (Urtica dioica L.). Herba Pol. 2009, 55, 84-93.

48. Naser Aldeen, M.G.; Mansoor, R.; AlJoubbeh, M. Fluctuations of phenols and flavonoids in infusion of lemon verbena (Lippia citriodora) dried leaves during growth stages. Nutr. Food Sci. 2015, 45, 766-773. [CrossRef]

49. Zeipina, S.; Alsina, I.; Lepse, L. Stinging nettle-The source of biologically active compounds as sustainable daily diet supplement. Res. Rural Dev. 2014, 20, 34-38.

50. Kong, D.X.; Li, Y.Q.; Wang, M.L.; Bai, M.; Zou, R.; Tang, H.; Wu, H. Effects of light intensity on leaf photosynthetic characteristics, chloroplast structure, and alkaloid content of Mahonia bodinieri (Gagnep.) Laferr. Acta Physiol. Plant. 2016, 38, 120. [CrossRef]

51. Pajevic, S.; Krstic, B.; Katic, S.; Nikolic, N.; Mihailovic, V. Some photosynthetic parameters of alfalfa (Medicago sativa L.) leaves at different phenological stages and in different cuttings. Matica Srp. Proc. Nat. Sci. 1999, 35. Available online: http: / / www.maticasrpska.org.rs/stariSajt/casopisi/prirodne_nauke_097.pdf\#page=38 (accessed on 18 January 2021).

52. Cândido, T.L.N.; Silva, M.R.; Agostini-Costa, T.S. Bioactive compounds and antioxidant capacity of buriti (Mauritia flexuosa Lf) from the Cerrado and Amazon biomes. Food Chem. 2015, 177, 313-319. [CrossRef]

53. Česlová, L.; Šilarová, P.; Fischer, J. Effect of harvesting and processing of stinging nettle on the antioxidant capacity of its infusions. Sci. Pap. Univ. Pardubice Ser. A Fac. Chem. Technol. 2016, 22, 23-33.

54. Kırca, A.; Arslan, E. Antioxidant capacity and total phenolic content of selected plants from Turkey. Int. J. Food Sci. Technol. 2008, 43, 2038-2046. [CrossRef] 